\title{
Poverty Reduction through Regional Integration : Technical Measures to Trade in Central America
}

José-Daniel Reyes

The World Bank, Washington DC, USA

Sinéad Kelleher

University College Dublin, Dublin, Ireland

\begin{abstract}
Despite the widespread tariff reductions sparked by the Dominican Republic-Central America Free Trade Agreement, anecdotal evidence suggests that borders in the region remain thick, with many hurdles standing in the way of regional integration. This paper uses a newly collected dataset to quantify the incidence of sanitary and phytosanitary measures and technical barriers to trade in the region. The results indicate that Central America has the lowest prevalence of technical non-tariff measures in the world. However, substantial heterogeneity is observed among countries. The paper estimates that the impact of sanitary and phytosanitary measures on border prices is equivalent to an ad-valorem tariff of $11.6 \%$. This effect is further investigated by looking in detail at the effect on the prices of beef, chicken meat, bread, and dairy products in Guatemala.
\end{abstract}

\footnotetext{
* Corresponding Author: José-Daniel Reyes; The World Bank, 1818 H St. NW, Washington, DC 20433, USA; Tel: +1 2024587052, E-mail: danielreyes@worldbank.org.

Co-Author: Sinéad Kelleher; School of Economics, University College Dublin, Belfield, Dublin 4, D04 V1W8, Ireland; Tel: +353 877548459, E-mail: kellehsp@tcd.ie. 
The impact is estimated to be equivalent to an ad-valorem tariff of $68.4 \%, 51.4 \%$, $22.0 \%$, and $5.0 \%$, respectively. The paper shows that efforts to streamline key sanitary and phytosanitary measures affecting these products by, for example, reducing the cost and time required to obtain sanitary registries, would likely reduce the Guatemalan urban extreme poverty rate from $5.07 \%$ to $4.91 \%$.

JEL Classifications: F13, F15, I32

Keywords: Trade Policy, Non-tariff Measures, Economic Integration, Poverty

\section{Introduction}

Broadly defined, Non-Tariff Measures (henceforth NTMs) are policy measures, other than ordinary customs tariffs, that may have an economic effect on international trade in goods by changing quantities traded, prices, or both (UNCTAD 2010). The fall in tariffs in recent decades has been accompanied by an increase in the importance of NTMs in the international trade agenda. NTMs allow countries to address legitimate non-trade objectives such as the protection of human, animal, and plant health. The World Trade Organization (WTO) recognizes that countries are entitled to use NTMs in this manner. However, there are concerns that the multilateral reduction of traditional trade barriers has tempted countries to replace tariffs with NTMs to protect domestic interests (Fischer and Serra 2000, Aisbett and Pearson 2012).

The potential benefits of NTMs are evident, but it is important for policy makers to be cognizant of the costs associated with them. Unlike traditional trade policy instruments, such as tariffs for which the associated price increases are well understood, the costs associated with NTMs are more difficult to immediately quantify. Even when used legitimately and without a protectionist intent, NTMs can have a major economic impact, potentially affecting regional integration, impacting domestic prices, diverting managerial attention, and penalizing small exporters. Countries imposing them may end up hurting their own poor as NTMs may increase the price of key staples and hampering the competitiveness of their own private sector as NTMs may affect the price of imported inputs.

This paper focuses on the role of NTMs in Central America and their implication for 
poverty. Anecdotal evidence suggests that NTMs raise trade costs and inhibit trade in the region (Cato et al. 2005, Gordillo et al. 2010). However, due to data limitation, there is a dearth of empirical papers quantifying the economic effects of these regulations. Seemingly simple questions such as what policy measures are imposed by a country? or what types of measures are faced by products that are important for the consumption basket? can often not be answered due to a lack of appropriate data.

In order to fill this gap, and in response to the increased interest of both policy makers and researchers in the region, in 2012 the World Bank, in collaboration with the United Nations Conference on Trade and Development (UNCTAD), collected NTM data in Nicaragua, Guatemala, El Salvador, Honduras, and Costa Rica. This endeavor complemented a multiagency effort to gather data worldwide (Cadot and Malouche 2012). This paper uses this new database to provide information about the incidence of NTMs and its implications for the welfare in the Central American region. We focus solely on the role of technical NTMs, namely Sanitary and Phytosanitary (SPS) measures and Technical Barriers to Trade (TBT).

This paper makes three key contributions to the literature on NTMs. (i) Using this new and comprehensive dataset, we provide a descriptive analysis of the trade incidence of SPS and TBT measures in five Central American countries and benchmark the region against other parts of the world. (ii) We use econometric techniques to estimate the effect of NTMs on consumer prices, and determine how this effect varies across countries and types of NTMs. (iii) We explore the poverty impact of streamlining NTMs in Guatemala, one of the poorest countries in the region.

Results indicate that the Central American region has the lowest prevalence of technical NTMs in the world. However, there is significant heterogeneity in the import coverage of NTMs across countries. Our analysis indicates that SPS measures inhibit intra-regional integration, with an average ad-valorem equivalent of $11.6 \%$. In particular, registration requirements for SPS reasons are identified as a possible obstacle to regional integration. We estimate the price-raising effect for four key products that are important in the consumption basket of Guatemala: beef, bread and pastry, chicken meat, and dairy products. According to our estimation, SPS measures affecting intra-regional trade of these products are equivalent to an ad-valorem tariff of $68.4 \%, 51.4 \%, 22.0 \%$, and $5.0 \%$, respectively.

Streamlining SPS measures in these products would contribute to poverty reduction in Guatemala. Rationalizing the implementation of burdensome SPS measures would reduce trade costs and, therefore, lessen consumer prices. This would, in turn, make 
the basic consumption basket more affordable, thereby benefitting the poorest segment of the population. Our computations suggest that streamlining the most significant SPS measures affecting beef, bread and pastry, chicken meat, and dairy products, for example, enforcing harmonization and mutual recognition of sanitary registries, could reduce the urban extreme poverty rate from $5.07 \%$ to $4.91 \%$.

The paper is structured as follows. Section II provides an overview of the current literature on NTMs, details their classification, and reports estimated frequency and coverage ratios. Section III assesses the price-raising effect of NTMs. Section IV presents a poverty analysis of streamlining SPS measures in Guatemala. The final section presents some concluding remarks.

\section{Non-Tariff Measures: Stylized facts}

Non-Tariff Measures are a very diverse set of regulations in terms of type, effect, and incidence. Governments have a large degree of autonomy regarding the form and objectives of NTMs, and there is a high level of variation in how they are implemented. In addition, the desired level of NTMs varies across countries depending on perceived levels of risk, public demand, and governmental priorities.

With the reduction of traditional trade barriers, NTMs have become the new frontier of trade policy. Their global significance in affecting the movement of goods across borders is large. Henson et al. (2000) asserts that "SPS measures are currently one of the foremost issues affecting exports of agricultural and food products from developing countries". Andriamananjara et al. (2004) report that the global welfare gains of the removal of certain NTMs would be in the order of 90 92 billion US dollars, while Walkenhorst and Yasui (2009) find that a reduction in transaction costs of 1 percent of the value of world trade would yield aggregate welfare gains of 40 billion US dollars.

Estimates of tariff equivalents of NTMs tend to be quite high. Bradford (2003) focuses on final goods trade and finds that the tariff equivalent of Japan's NTMs is 57\%. The tariff equivalent for European countries' NTMs is slightly lower, ranging from $48 \%$ to $55 \%$, and much lower for the United States at just 12\%. Calvin and Krissoff (1998) use a price gap approach and show that the tariff equivalent of NTMs on the US apples exported to Japan is $27.2 \%$. This estimate significantly exceeds the average tariff rate 
of $19.3 \%$. Chemingui and Dessus (2008) find that NTMs increase the domestic price of imported goods by an average of $17 \%$ across all product categories in Syria. By contrast, the average tariff is just $8 \%$. Kee et al. (2009) find that NTMs add, on average, an additional $87 \%$ to the level of trade restrictiveness imposed by tariffs, and note that for 34 countries of a sample of 78, the contribution of NTMs to the overall level of restrictiveness is higher than the contribution of tariffs. Results from surveys also show that NTMs can be a key factor impeding the ability of firms to export agricultural goods (Henson et al. 2000).

However, NTMs cannot be simply dismissed as trade barriers. Results from gravity type models including Disdier et al. (2008), Fontagné et al. (2005), Portugal-Perez et al. (2010), and Reyes (2011) indicate that while NTMs are generally found to be impediments to trade, they can also be trade promoting. This is because certain NTMs, such as labeling and content requirements, can provide consumers with information thereby lowering transaction costs, facilitating comparison, and reducing uncertainty. Thus, NTMs can eliminate a market failure by reducing the cost of determining the quality of a product, thereby helping to prevent a lemon problem (Akerlof 1970). This point is also made by Crivelli and Gröschl (2012), Disidier et al. (2008), and Ganslandt and Markusen (2001).

Regardless of their impact on aggregate trade flows, small and developing countries find it more difficult to comply with NTMs. Reyes (2012) highlights the interplay between standards harmonization and market structure. Using firm-level data, the author finds that the international harmonization of European standards in the electronic sector increases intra-EU competition to the benefit of exporters from the US but to the disadvantage of exporters from the developing world, who lose market share. Ganslandt and Markusen's (2001) general equilibrium model finds that incompatible standards are especially harmful for a small country, which can never win a standards' war, where two countries impose cost-increasing standards on imports. In the small country, both producers and consumers may lose. Finally, Disdier et al. (2008) find that developing and least developed countries' exports to the Organization for Economic Co-operation and Development (OECD) are significantly reduced by SPS and TBT measures. By contrast, these regulations do not have any effect on exports from other OECD states. 


\section{A. Taxonomy of non-tariff measures}

In 2006, the Secretary-General of UNCTAD established the Group of Eminent Persons on Non-Tariff Barriers (GNTB). Their objective was to discuss the definition, classification, collection, and quantification of NTMs. The GNTB established a Multi-Agency Support Team (MAST) which comprised representatives from several international organizations. ${ }^{1}$ Following a series of meetings and consultations, the MAST proposed a nomenclature that comprises a tree/branch structure. Measures with similar objectives are categorized into 16 branches (chapters) denoted by alphabetical letters A to P. Each of these branches is further disaggregated into sub-branches (1-digit), twigs (2-digits), and leafs (3-digits) allowing for a finer classification of NTMs. Technical measures are classified in chapters A, B, and C, corresponding to Sanitary and Phytosanitary measures (SPS), Technical Barriers to Trade (TBT), and pre-shipment inspections and other formalities, respectively. UNCTAD (2012) provides the NTM nomenclature at the highest degree of disaggregation.

Following the establishment of the classification, an effort to collect comprehensive NTM data is currently being undertaken jointly by the World Bank, UNCTAD, and the African Development Bank. This process includes the collection of trade-related regulations and their classification into NTM and product codes. The data is carefully scrutinized for possible duplications, omissions, or any other problems in order to minimize inaccuracies. Once the gathered data are verified, it is uploaded onto World Integrated Trade Solution (WITS), the World Bank's portal for trade data, where it is publicly available.

\section{B. Data availability}

At the time of writing, NTM data has been collected for 46 developing countries, with 33 of the data files publically available on the World Integrated Trade Solution (WITS) platform - the World Bank gateway for trade data and analysis. ${ }^{2}$ The remaining data files are in the process of verification by UNCTAD. Table 1 shows the availability

\footnotetext{
MAST members included the Food and Agriculture Organization of the United Nations (FAO), the International Monetary Fund (IMF), the International Trade Centre UNCTAD/WTO (ITC), the Organization for Economic Co-operation and Development (OECD), the United Nations Industrial Development Organization (UNIDO), the World Bank, and the World Trade Organization (WTO).

${ }^{2}$ http://wits.worldbank.org.
} 
of data across six world regions, along with the year in which the data was collected. ${ }^{3}$ The table separates out the five Central American countries that are the subject of our analysis.

\section{Table 1. Non-tariff measures data availability}

\begin{tabular}{|c|c|c|c|c|c|c|}
\hline $\begin{array}{l}\text { Sub-Saharan } \\
\text { Africa }\end{array}$ & $\begin{array}{l}\text { East Asia } \\
\text { and Pacific }\end{array}$ & $\begin{array}{l}\text { Europe and } \\
\text { Central Asia }\end{array}$ & $\begin{array}{l}\text { Latin America } \\
\text { and Caribbean }\end{array}$ & $\begin{array}{l}\text { Central } \\
\text { America }\end{array}$ & $\begin{array}{l}\text { Middle East and } \\
\text { North Africa }\end{array}$ & South Asia \\
\hline $\begin{array}{l}\text { Burkina Faso* } \\
\text { (2010) }\end{array}$ & $\begin{array}{l}\text { Cambodia } \\
\text { (2011) }\end{array}$ & $\begin{array}{c}\text { Kazakhstan* } \\
(2012)\end{array}$ & $\begin{array}{l}\text { Argentina* } \\
\text { (2008) }\end{array}$ & $\begin{array}{l}\text { Costa Rica* } \\
\text { (2012) }\end{array}$ & $\begin{array}{l}\text { Egypt* } \\
(2011)\end{array}$ & $\begin{array}{l}\text { Afghanistan* } \\
\text { (2012) }\end{array}$ \\
\hline $\begin{array}{l}\text { Kenya } \\
(2011)\end{array}$ & $\begin{array}{l}\text { China* } \\
(2012)\end{array}$ & $\begin{array}{l}\text { Russia } \\
(2009)\end{array}$ & $\begin{array}{l}\text { Bolivia* } \\
(2008)\end{array}$ & $\begin{array}{c}\text { El Salvador } \\
\text { (2012) }\end{array}$ & $\begin{array}{l}\text { Lebanon* } \\
\text { (2011) }\end{array}$ & $\begin{array}{l}\text { Bangladesh } \\
\text { (2011) }\end{array}$ \\
\hline $\begin{array}{l}\text { Madagascar* } \\
\quad(2011)\end{array}$ & $\begin{array}{l}\text { Lao PDR* } \\
\quad(2011)\end{array}$ & $\begin{array}{l}\text { Turkey } \\
(2010)\end{array}$ & $\begin{array}{l}\text { Brazil* } \\
(2008)\end{array}$ & $\begin{array}{l}\text { Guatemala* } \\
\text { (2012) }\end{array}$ & $\begin{array}{l}\text { Morocco* } \\
(2011)\end{array}$ & $\begin{array}{l}\text { India* } \\
(2012)\end{array}$ \\
\hline $\begin{array}{l}\text { Malawi } \\
(2011)\end{array}$ & $\begin{array}{c}\text { Philippines } \\
\text { (2008) }\end{array}$ & & $\begin{array}{l}\text { Chile* } \\
(2008)\end{array}$ & $\begin{array}{l}\text { Honduras } \\
(2012)\end{array}$ & $\begin{array}{c}\text { Syrian Arab Rep. } \\
\text { (2011) }\end{array}$ & $\begin{array}{l}\text { Nepal* }^{*} \\
(2012)\end{array}$ \\
\hline $\begin{array}{l}\text { Mauritius* } \\
\text { (2011) }\end{array}$ & $\begin{array}{l}\text { Indonesia } \\
(2011)\end{array}$ & & $\begin{array}{l}\text { Colombia* } \\
\text { (2008) }\end{array}$ & $\begin{array}{l}\text { Nicaragua } \\
(2012)\end{array}$ & $\begin{array}{l}\text { Tunisia* } \\
\text { (2011) }\end{array}$ & $\begin{array}{c}\text { Pakistan* } \\
\text { (2012) }\end{array}$ \\
\hline $\begin{array}{l}\text { Namibia* } \\
\text { (2011) }\end{array}$ & & & $\begin{array}{c}\text { Ecuador* } \\
\text { (2008) }\end{array}$ & & & $\begin{array}{l}\text { Sri Lanka* } \\
\text { (2012) }\end{array}$ \\
\hline $\begin{array}{l}\text { Rwanda } \\
\text { (2011) }\end{array}$ & & & $\begin{array}{c}\text { Mexico* } \\
(2008)\end{array}$ & & & \\
\hline $\begin{array}{l}\text { Senegal* } \\
(2011)\end{array}$ & & & $\begin{array}{c}\text { Paraguay* } \\
\text { (2008) }\end{array}$ & & & \\
\hline $\begin{array}{l}\text { South Africa } \\
\text { (2011) }\end{array}$ & & & $\begin{array}{l}\text { Peru* } \\
(2008)\end{array}$ & & & \\
\hline $\begin{array}{c}\text { Tanzania* } \\
\text { (2011) }\end{array}$ & & & $\begin{array}{l}\text { Uruguay* } \\
\text { (2008) }\end{array}$ & & & \\
\hline $\begin{array}{l}\text { Uganda } \\
\text { (2011) }\end{array}$ & & & $\begin{array}{l}\text { Venezuela* } \\
\text { (2008) }\end{array}$ & & & \\
\hline
\end{tabular}

(Notes) (i) The year in which NTM data was collected is in parentheses.

(ii) * indicates those countries for which the NTM data are publically available in WITS as of June 2013. (Source) Authors' computation.

\footnotetext{
${ }^{3}$ The regions follow the classification of the World Bank, with the exception of Central American countries that are classified in the Latin America and the Caribbean region.
} 
For the purposes of our analysis, a standardized methodology was developed in order to harmonize each country's NTM data. Firstly, we only used those NTMs that applied to each of a country's trading partners in the analysis. Secondly, we standardized product codes at the 6-digits of the 2002 version of the HS classification. Thirdly, we harmonized the NTM classification to the 2012 version. ${ }^{4}$ Finally, the data was checked to ensure no duplications at the country-product-NTM code level, and we dropped from the analysis SPS and TBT measures that were applied to all products as these were assumed to be data entry mistakes. In total, we work with 46 country files, accounting for a database of around 2 million observations.

\section{Trade incidence of non-tariff measures}

Two simple inventory indicators are used to measure the prevalence of NTMs: the frequency ratio, i.e., percentage of product lines exposed to NTMs and the coverage ratio, which is the share of total imports exposed to NTMs. The frequency ratio accounts only for the presence or absence of an NTM, and indicates the percentage of imported products to which one or more NTMs are applied. In more formal terms, the frequency ratio of NTMs imposed by country $j\left(F_{j}\right)$ is calculated as:

$$
F_{j}=\left[\frac{\sum D_{i} M_{i}}{\sum M_{i}}\right] \times 100
$$

where $D_{i}$ is a dummy variable indicating the presence of one or more NTMs and $M_{i}$, a dummy variable indicates whether there are imports of good $i$. Because all products have equal weights, this measure tends to overemphasize products with very low import value.

A measure of the importance of NTMs in terms of overall import value is given by the coverage ratio. This indicator measures the percentage of imports to country $j$ subject to at least one NTM. In formal terms the coverage ratio $\left(C_{j}\right)$ is given by:

$$
C_{j}=\left[\frac{\sum D_{i} V_{i}}{\sum V_{i}}\right] \times 100
$$

\footnotetext{
${ }^{4}$ After the establishment of the first NTM classification in 2008, the NTM taxonomy was reviewed and updated in 2009 and 2012.
} 
where $D_{i}$ is defined as before, and $V_{i}$ is the value of imports of product $i$. Unlike the previous indicator, the coverage ratio does not overemphasize products with a low import value, but because products affected by trade restricting measures are imported in lower quantities and therefore get a lower weight in the calculation, it tends to underestimate the overall restrictiveness, i.e., endogeneity bias.

Neither the frequency ratio nor the coverage ratio makes any distinction between NTMs with relatively little impact on trade and those with major, even prohibitive, trade effects. This is a significant issue as restrictiveness varies widely across different types of NTMs; Beghin and Bureau (2001) note that there is not even a clear correlation between the number of NTMs in place and their trade effect. Also, it should be noted that frequency and coverage ratios do not give any indication of the level of enforcement by regulations. Because neither of these standard measures is perfect, both is presented. Despite their shortcomings, they provide useful information about what is most often observed in a country, what is likely to be important, and thus what may warrant a deeper analysis.

This paper focuses on SPS (chapter A) and TBT (chapter B) measures, both of which are technical NTMs. Central America is the region where these measures are least prevalent as shown in Figure 1. Figure 1 presents the within regions' simple average of frequency and coverage ratios. On average, approximately $22.3 \%$ of active tariff lines in the region are affected by at least one NTM, and one third of imports are subject to an NTM. While the Middle East and North Africa has the highest frequency ratio, Europe and Central Asia has the highest coverage ratio indicating differences in the relative composition of their import baskets.

${ }^{5}$ We use the average total import value by product (6-digit HS codes) in the period 2008 2010. 


\section{Figure 1. Technical non-tariff measures}

(World regions)

(Average 2008 2010, \%)

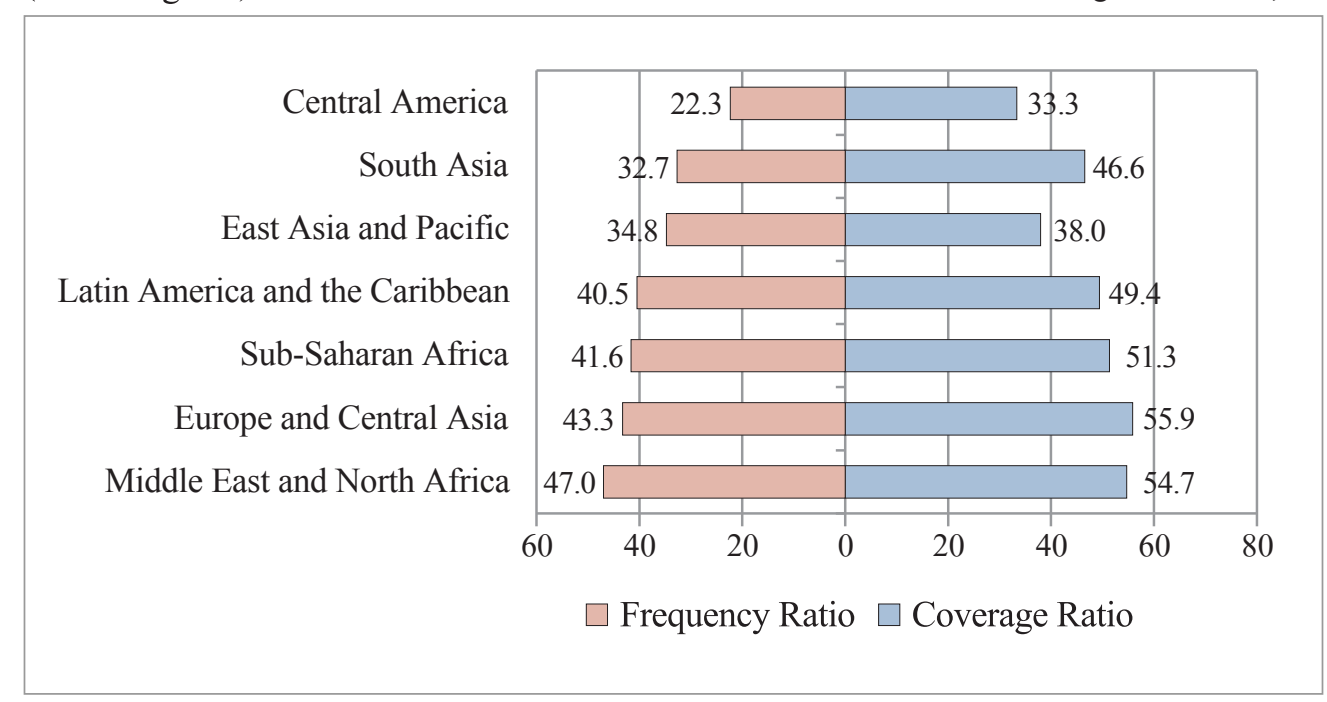

(Notes) (i) Only SPS and TBT measures are considered.

(ii) The countries considered for this analysis are listed in Table 1.

(Source) Authors' computation.

Central American countries differ greatly in their use of NTMs which indicates that there is not one common approach to trade regulation in the region. Figure 2 shows that the more developed countries appear to utilize NTMs more intensely than their less developed neighbors. El Salvador applies NTMs to the highest proportion of import lines $(32.2 \%)$, which is more than double the proportion of imported goods subject to an NTM in Honduras (15.0\%). This heterogeneity may be an indication of differences in governmental priorities and approaches towards trade regulation, composition of import baskets, or the influence of import-competing sectors lobbying for protection. 


\section{Figure 2. Technical non-tariff measures}

(Central America)

(Average 2008 2010, \%)

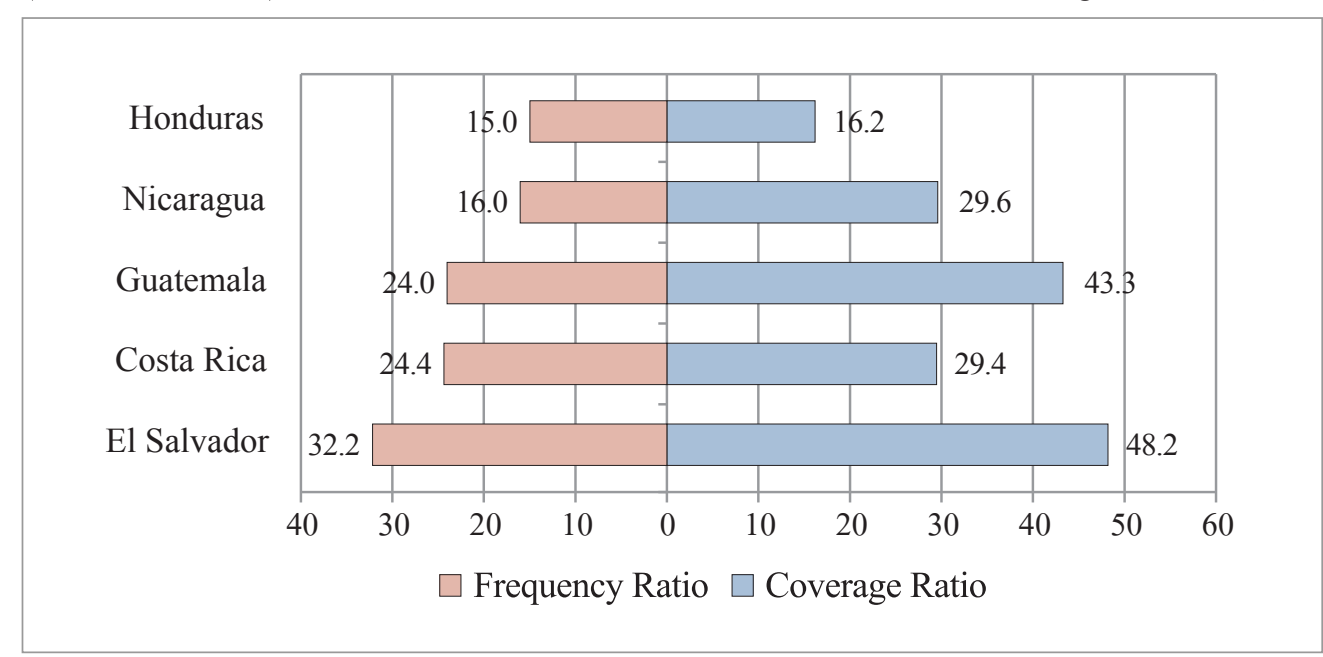

(Notes) (i) This figure presents the frequency and coverage ratios for all Central American countries.

(ii) Only SPS and TBT measures are considered.

(Source) Authors' computation.

Central American countries also differ in the incidence of technical NTMs across type of measures and economic sectors. Table 2 displays the coverage ratios for SPS and TBT measures across economic sectors. The last row shows the share of total import value covered by at least one SPS or TBT measure across countries. Results indicate that SPS regulation affect, on average, around $18 \%$ of total import value in Central America. The incidence of SPS in El Salvador is the highest in the region with a coverage ratio of $21.6 \%$ whereas Honduras shows the lowest incidence with a coverage ratio of $16.2 \%$. There is a much wider variation in the use of TBT, with only $7.9 \%$ of Honduran imports covered by a TBT regulation compared to $42.3 \%$ of goods imported to El Salvador. For most countries, the coverage ratio for TBT regulations is significantly larger than the frequency ratio. This suggests that these countries import large volumes of products from sectors that use TBTs more extensively. Table 2 also reports coverage ratios across economic sectors. Each cell represents the import value affected by at least one type of NTM as a share of total sectoral import value. This analysis reveals that SPS measures are primarily concentrated in animal, vegetable, and foodstuff sectors, while TBTs are especially prevalent in trade in animals and chemical goods, but are also used intensively in the vegetable and foodstuffs sectors. 
Table 2. Non-tariff measures within economic sectors

(Central America, Coverage ratios)

(Average 2008 2010, \%)

\begin{tabular}{|c|c|c|c|c|c|c|c|c|c|c|}
\hline & \multicolumn{5}{|c|}{ A. Sanitary and Phytosanitary Measures } & \multicolumn{5}{|c|}{ B. Technical Barriers to Trade } \\
\hline & CRI & SLV & GTM & HND & NIC & CRI & SLV & GTM & HND & NIC \\
\hline 01-05 Animal & 78.8 & 100.0 & 100.0 & 100.0 & 90.5 & 58.8 & 97.5 & 95.4 & 57.5 & 46.8 \\
\hline 06-15 Vegetable & 68.8 & 98.4 & 99.8 & 85.9 & 99.8 & 45.0 & 32.1 & 78.8 & 24.2 & 91.1 \\
\hline 16-24 Foodstuffs & 83.3 & 87.5 & 98.7 & 78.5 & 77.7 & 35.5 & 85.9 & 81.8 & 21.5 & 34.6 \\
\hline 25-26 Minerals & 93.3 & 11.8 & 9.1 & 2.9 & 2.8 & 51.1 & 52.7 & 12.5 & - & 82.2 \\
\hline $27 \quad$ Oil Minerals & 44.3 & 16.8 & - & 2.9 & 0.0 & 44.3 & 97.7 & 95.2 & - & 4.6 \\
\hline 28-38 Chemicals & 36.4 & 9.0 & 40.8 & 19.5 & 13.8 & 81.4 & 98.5 & 74.0 & 4.5 & 63.7 \\
\hline 39-40 Plastic/Rubber & 0.2 & 0.8 & - & - & - & 1.6 & 44.1 & 1.4 & - & - \\
\hline 41-43 Hides, Skins & 44.1 & 42.1 & 41.2 & - & - & - & 28.5 & - & - & - \\
\hline 44-49 Wood & - & 3.8 & 1.6 & - & - & 3.8 & 0.0 & - & - & - \\
\hline 50-63 Textiles, Clothing & 0.3 & 5.1 & 4.0 & - & - & 0.1 & - & - & - & - \\
\hline 64-67 Footwear & - & 0.5 & 0.0 & - & - & - & 2.4 & - & - & - \\
\hline 68-71 Stone / Glass & - & - & - & 4.0 & 2.1 & 0.3 & - & - & - & 2.1 \\
\hline 72-83 Metals & - & - & - & 0.0 & 0.0 & 0.0 & 0.3 & 0.3 & - & 0.0 \\
\hline 84-85 Mach/Elec & 1.0 & - & - & - & - & 9.2 & 0.0 & 2.9 & - & - \\
\hline All sectors & 16.2 & 21.6 & 19.4 & 16.1 & 16.6 & 25.9 & 42.3 & 40.4 & 7.9 & 25.0 \\
\hline
\end{tabular}

(Notes) (i) Each country is labeled by its 3-digit ISO code.

(ii) Abbreviations are as follows; CRI = Costa Rica, SLV = El Salvador, GTM = Guatemala, HND = Honduras, NIC = Nicaragua.

(Source) Authors' computation.

Registration requirements for importers are one of the most common technical measures to trade in Central America. Table 3 shows the top 10 most important NTMs in terms of their coverage ratio in each country. Different types of registration requirements are highlighted in grey. These requirements are applied not only on importers (codes B150 and A150) but also on selected imported products (codes B810 and A810). Central American countries use this type of regulation more frequently than other countries for which data is available. Appendix 1 compares the use of registration requirements for SPS reasons (code A150), the so called sanitary registries in Central America to other countries in the world. 


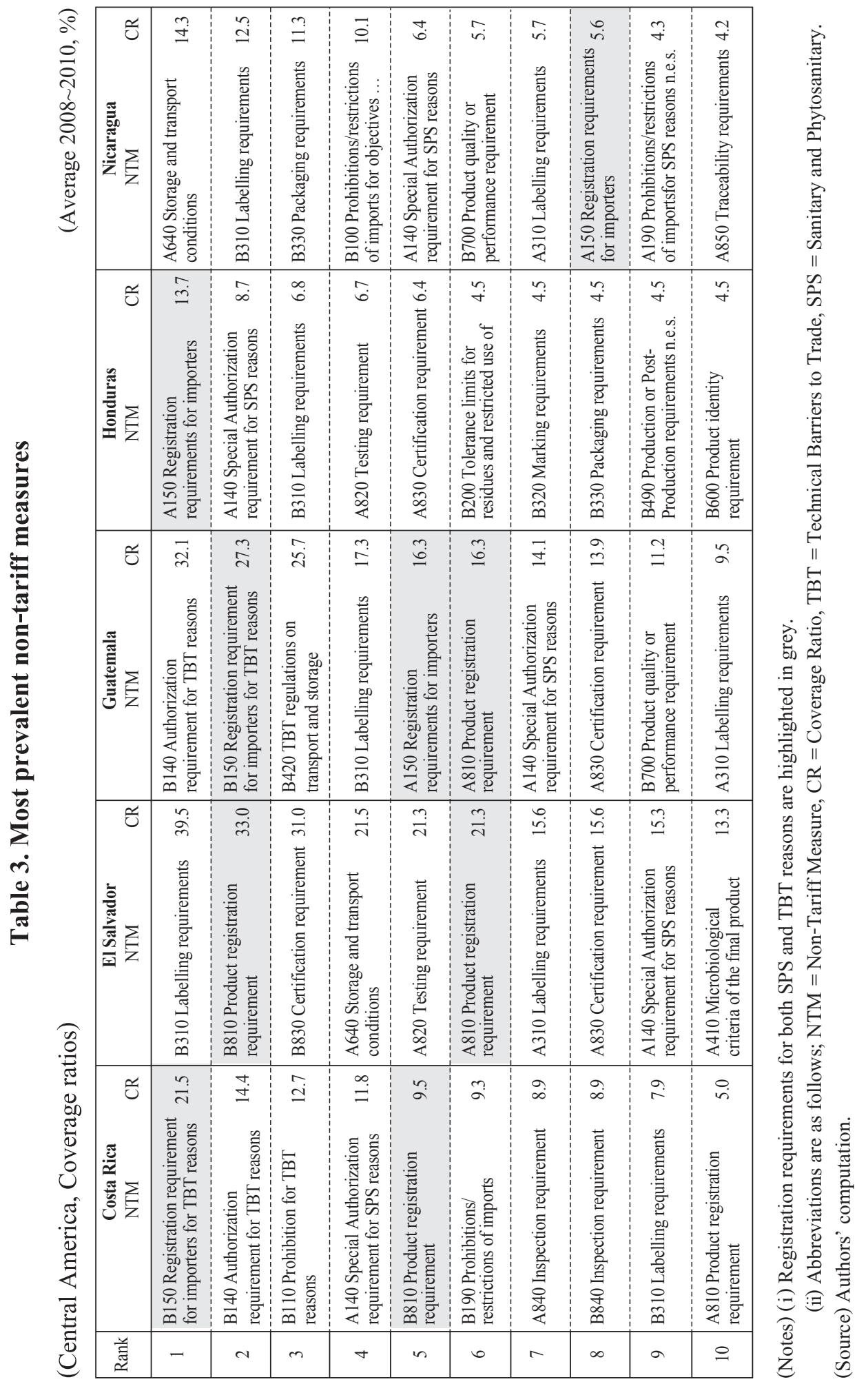


SPS measures disproportionally affect intra-regional trade in Central America. Figure 3 compares total coverage ratios in the region, computed using total imports (X-axis), versus regional coverage ratios, computed using regional imports ( $\mathrm{Y}$-axis), for SPS and TBT measures. Each dot represents an NTM code, at the highest level of disaggregation. An NTM located above the 45 degree line indicates that it affects more imports from regional trading partners than imports from all countries in the world. This analysis shows that while TBT measures are relatively balanced across trading partners, SPS measures fall heavily on intra-regional trade.

Figure 3. Incidence of technical non-tariff measures in intra-regional trade

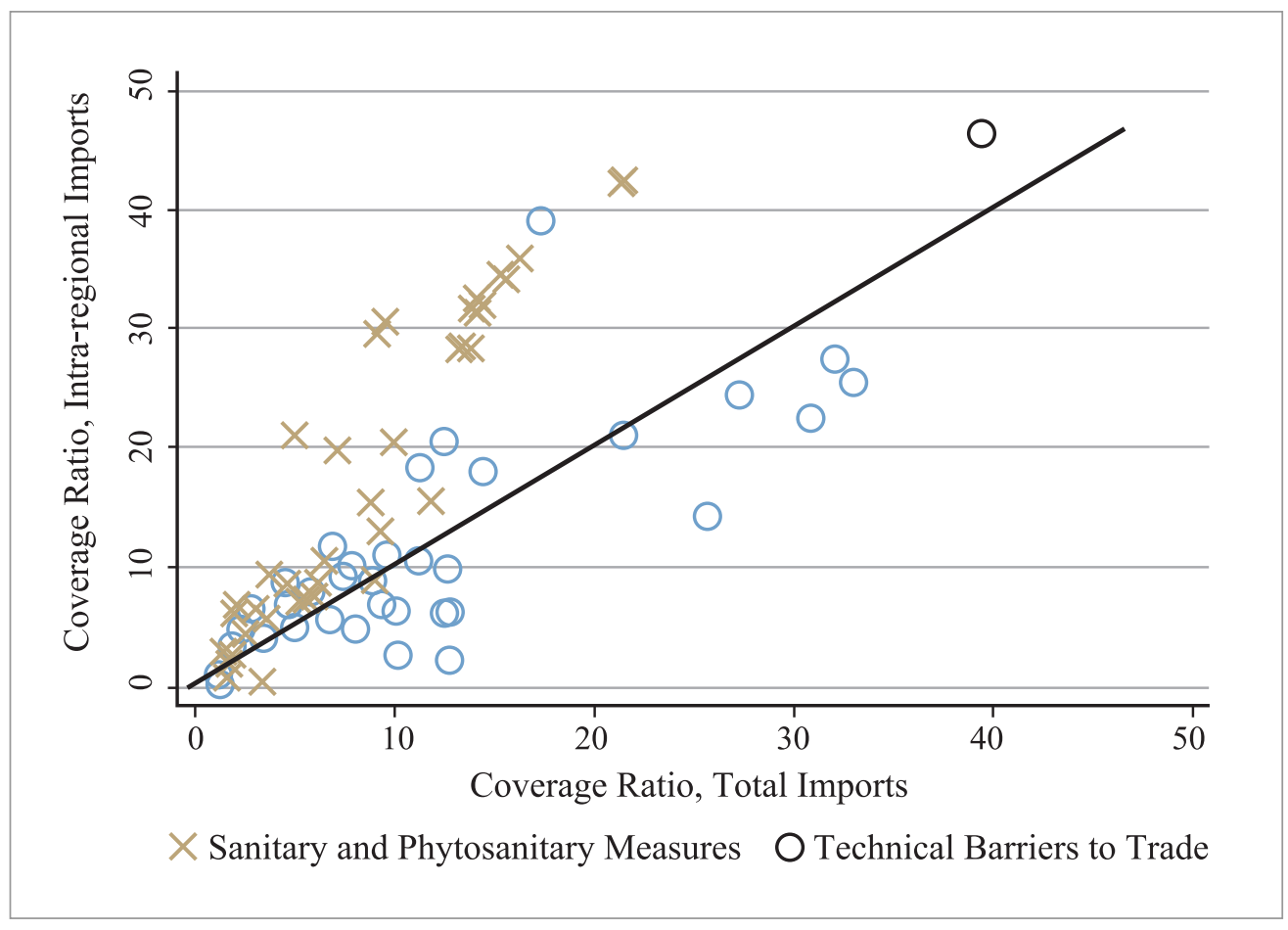

(Notes) Each point represents an NTM code, at the highest level of disaggregation. Data are plotted for Costa Rica, El Salvador, Guatemala, Honduras, and Nicaragua.

(Source) Authors' computation. 


\section{Price-raising Effects}

This section employs price data matched with NTM information for 46 countries to estimate ad-valorem equivalents. Using a simple price determination model, we estimate the stringency of SPS and TBT measures in the Central American region as a whole and country by country.

\section{A. Price data}

Trade unit values from the French Research Center in International Economics (CEPII) are used to approximate trade prices. ${ }^{6}$ These data provide reliable and comparable unit values across countries. The Cost of Insurance and Freight (CIF) trade unit values reported by the importer country are used to estimate any potential price-raising effects of NTMs. The CIF price was deemed most appropriate for the analysis as it includes the Freight On Board (FOB) price of the product along with the cost of compliance with SPS and TBT regulations, and any other expenses from pre-shipment inspection, licensing, or any other sort of NTM.

\section{B. Methodology}

The methodology follows Cadot and Gourdon (2012, 2014). Prices are assumed to be determined by Equation (3). Here, $i$ indexes countries, $k$ indexes products, $p_{k}^{*}$ is the world price of product $k, p_{i k}$ is its price in country $i, t_{i k}$ is the tariff imposed by country $i$ on product $k$, and $\lambda_{i}$ is a cost-of-living adjustment factor for country $i$ depending on its level of income and a number of other characteristics such as landlocked status, remoteness, the quality of the infrastructure, and the regulatory environment. $\delta_{i j k}$ is a dummy variable that equals one if country $i$ imposes an NTM of type $j$ on product $k$, and zero otherwise. Let $a_{j}$ be the cost of complying with NTM of type $j$, assumed to be constant across countries and products. Assuming that tariffs and NTM compliance costs are fully

\footnotetext{
${ }^{6}$ This database provides a world-level dataset reporting reliable unit values at a high level of disaggregation. One shortcoming is important to note: despite the treatment of missing unit values in the database, there is still a relatively large share of missing data. Berthou and Emlinger (2011) estimate that the database covered around 80\% of world total trade values in 2008 .
} 
passed through to domestic prices, the basic price determination equation is:

$$
p_{i k}=p_{k}^{*}\left(1+\lambda_{i}\right)\left(1+t_{i k}\right) \Pi_{j}\left(1+a_{j} \delta_{i j k}\right)
$$

Logging Equation (3) yields:

$$
\ln p_{i k}=\ln p_{k}^{*}+\ln \left(1+\lambda_{i}\right)+\ln \left(1+t_{i k}\right)+\Sigma_{j} \ln \left(1+a_{j} \delta_{i j k}\right)
$$

Due to our assumption of perfect tariff pass-through, we can redefine our dependent variable as:

$$
\ln \tilde{p}_{i k}=\ln p_{i k}-\ln \left(1+t_{i k}\right)
$$

Also note that:

$$
\ln \left(1+a_{j} \delta_{i j k}\right)= \begin{cases}\ln \left(1+a_{j}\right) & \text { if } \delta_{i j k}=1 \\ 0 & \text { if } \delta_{i j k}=0\end{cases}
$$

So, $\ln \left(1+a_{j} \delta_{i j k}\right)=\delta_{i j k} \ln \left(1+a_{j}\right)$.

Let $\gamma_{k}=\ln p_{k}^{*}$ and $\gamma_{i}=\ln \left(1+\lambda_{i}\right)$. Using this result, and letting $u_{i k}$ be the error term, the basic estimation equation is:

$$
\ln \tilde{p}_{i k}=\gamma_{k}+\gamma_{i}+\sum_{j} \beta_{j} \delta_{i j k}+u_{i k}
$$

where $\gamma_{k}$ and $\gamma_{i}$ are product and country fixed effects, respectively. Note that the algebraic interpretation of the estimated coefficient $\widehat{\beta}_{J}$ is:

$$
\begin{gathered}
\widehat{\beta}_{J}=\ln \left(1+\widehat{a}_{J}\right) \\
\text { or } \\
\widehat{a}_{J}=e^{\widehat{\widehat{J}_{J}}-1}
\end{gathered}
$$

where $\widehat{a}_{J}$ is the estimated Ad-Valorem Equivalent (AVE) of NTM type $j$. 


\section{Results}

NTMs are positively and significantly related to border prices across our sample of countries. Table 4 shows the baseline regressions results. The first and third specifications use a dummy variable to indicate the presence of an NTM, while the second and fourth specifications use the count of NTMs applied at the product level. Standard gravity type controls are used. Bilateral data on distance between two countries, common language, contiguity, and common colonizer since 1945 are sourced from CEPII, and GDP figures come from the World Bank's World Development Indicators database. Three variables on endowments are used, physical capital stock per worker, arable land per worker, and education per worker. These figures are sourced from Shirotori et al. (2010). After controlling for systematic cross-country cost-of-living differences, and partner and product specific unobservables, we find that the presence of at least one technical NTM increases domestic prices by $10.6 \%(\exp (0.101)-1)$ on average across all 46 countries for which data are available. If we interpret the coefficient with the number of NTMs as the increase in domestic prices of adding one additional NTM regardless of type, then an additional NTM increases domestic prices by an average of $2.2 \%(\exp (0.022)-1)$. 
Table 4. Price-raising effect of non-tariff measures

(CIF Unit Values)

\begin{tabular}{|c|c|c|c|c|}
\hline Specification Variables & $\begin{array}{c}\text { NTM } \\
\text { dummy } \\
(1)\end{array}$ & $\begin{array}{c}\text { Log number } \\
\text { of NTMs } \\
(2)\end{array}$ & $\begin{array}{c}\text { NTM } \\
\text { dummy } \\
(3)\end{array}$ & $\begin{array}{c}\text { Log number } \\
\text { of NTMs } \\
(4)\end{array}$ \\
\hline$N T M$ & $\begin{array}{c}0.101 * * * \\
(0.008)\end{array}$ & $\begin{array}{c}0.022 * * * \\
(0.001)\end{array}$ & & \\
\hline SPS & & & $\begin{array}{c}0.194 * * * \\
(0.011)\end{array}$ & $\begin{array}{c}0.023 * * * \\
(0.002)\end{array}$ \\
\hline$T B T$ & & & $\begin{array}{l}-0.015^{*} \\
(0.009)\end{array}$ & $\begin{array}{c}0.019 * * * \\
(0.003)\end{array}$ \\
\hline $\log (G D P)$ & $\begin{array}{c}-0.082 * * * \\
(0.003)\end{array}$ & $\begin{array}{c}-0.087 * * * \\
(0.003)\end{array}$ & $\begin{array}{c}-0.083 \text { *** } \\
(0.003)\end{array}$ & $\begin{array}{c}-0.087^{*} * * \\
(0.003)\end{array}$ \\
\hline $\log ($ Distance $)$ & $\begin{array}{c}0.155^{* * *} \\
(0.004)\end{array}$ & $\begin{array}{c}0.161^{* * *} \\
(0.004)\end{array}$ & $\begin{array}{c}0.158^{* * *} \\
(0.004)\end{array}$ & $\begin{array}{c}0.161^{* * *} \\
(0.004)\end{array}$ \\
\hline $\log (H / L)$ & $\begin{array}{c}0.713^{* * *} \\
(0.013)\end{array}$ & $\begin{array}{c}0.704 * * * \\
(0.013)\end{array}$ & $\begin{array}{c}0.694 * * * \\
(0.013)\end{array}$ & $\begin{array}{c}0.705 * * * \\
(0.013)\end{array}$ \\
\hline $\log (T / L)$ & $\begin{array}{c}-0.160^{* * *} \\
(0.004)\end{array}$ & $\begin{array}{c}-0.151^{* * *} \\
(0.004)\end{array}$ & $\begin{array}{c}-0.156^{* * *} \\
(0.004)\end{array}$ & $\begin{array}{c}-0.151^{* * *} \\
(0.004)\end{array}$ \\
\hline $\log (K / L)$ & $\begin{array}{c}0.367^{* * *} \\
(0.005)\end{array}$ & $\begin{array}{c}0.375^{* * *} \\
(0.005)\end{array}$ & $\begin{array}{c}0.369^{* * *} \\
(0.005)\end{array}$ & $\begin{array}{c}0.375^{* * *} \\
(0.005)\end{array}$ \\
\hline Contiguity & $\begin{array}{c}-0.071 * * * \\
(0.007)\end{array}$ & $\begin{array}{c}-0.065^{* * *} \\
(0.007)\end{array}$ & $\begin{array}{c}-0.068 * * * \\
(0.007)\end{array}$ & $\begin{array}{c}-0.065^{* * *} \\
(0.007)\end{array}$ \\
\hline Common Official Language & $\begin{array}{c}0.120^{* * *} \\
(0.008)\end{array}$ & $\begin{array}{c}0.115^{* * *} * \\
(0.008)\end{array}$ & $\begin{array}{c}0.119^{* * *} \\
(0.008)\end{array}$ & $\begin{array}{c}0.114^{* * *} * \\
(0.008)\end{array}$ \\
\hline Common Ethnical Language & $\begin{array}{c}-0.081^{* * *} \\
(0.008)\end{array}$ & $\begin{array}{c}-0.071^{* * *} \\
(0.008)\end{array}$ & $\begin{array}{c}-0.072 * * * \\
(0.008)\end{array}$ & $\begin{array}{c}-0.071^{* * *} \\
(0.008)\end{array}$ \\
\hline Common Colonizer & $\begin{array}{c}0.007 \\
(0.010)\end{array}$ & $\begin{array}{c}0.006 \\
(0.010)\end{array}$ & $\begin{array}{c}0.006 \\
(0.010)\end{array}$ & $\begin{array}{c}0.007 \\
(0.009)\end{array}$ \\
\hline Constant & $\begin{array}{c}3.088^{* * *} \\
(0.099)\end{array}$ & $\begin{array}{c}3.123^{* * *} \\
(0.100)\end{array}$ & $\begin{array}{c}3.104^{* * *} \\
(0.100)\end{array}$ & $\begin{array}{c}3.127^{* * *} * \\
(0.099)\end{array}$ \\
\hline Exporter FE & Yes & Yes & Yes & Yes \\
\hline Product FE & Yes & Yes & Yes & Yes \\
\hline Observations & $1,922,527$ & $1,922,527$ & $1,922,527$ & $1,922,527$ \\
\hline$R$-squared & 0.587 & 0.588 & 0.589 & 0.589 \\
\hline
\end{tabular}

(Notes) (i ) Robust standard errors adjusted for clustering at the product (6-digit HS codes) level are in parentheses.

(ii) All regressions include exporter and product fixed effects.

(iii) *** significant at the $1 \%$ level; ** significant at the $5 \%$ level; * significant at the $10 \%$ level.

(Source) Authors' computation. 
Our results also indicate that SPS measures are positively and significantly related to an increase in border prices. The price increase arising from SPS measures is equivalent to an ad-valorem tariff of $21.4 \%$ across all countries and products in the dataset (column 3). By contrast, TBT measures are negatively related to border price with an estimated AVE of $-1.5 \%$. The coefficient for TBT is significant only at the $10 \%$ level. A negative AVE indicates a net trade-facilitating effect, which may be the result of positive externalities arising from the TBT outweighing its compliance costs (Beghin et al. 2013). The signs and significance of the control variables are generally as expected.

In order to explore the impact of SPS and TBT measures on border prices across geographic regions, we use specification 3 and interact the SPS and TBT dummies variables with a dummy for each world region. Results are presented in Appendix 2 and graphically depicted in Figure 4 and Figure 5 for SPS and TBT measures, respectively. We find that SPS regulations in Central America are positively and significantly related to an increase in border prices, and have a price effect equivalent to a tariff of $11.6 \%$. This AVE, however, is small compared to that experienced in the Asian and the SubSaharan African regions, but close to the rest of the Latin America and the Caribbean region. 


\section{Figure 4. Price-raising effect of SPS Measures}

(World regions)

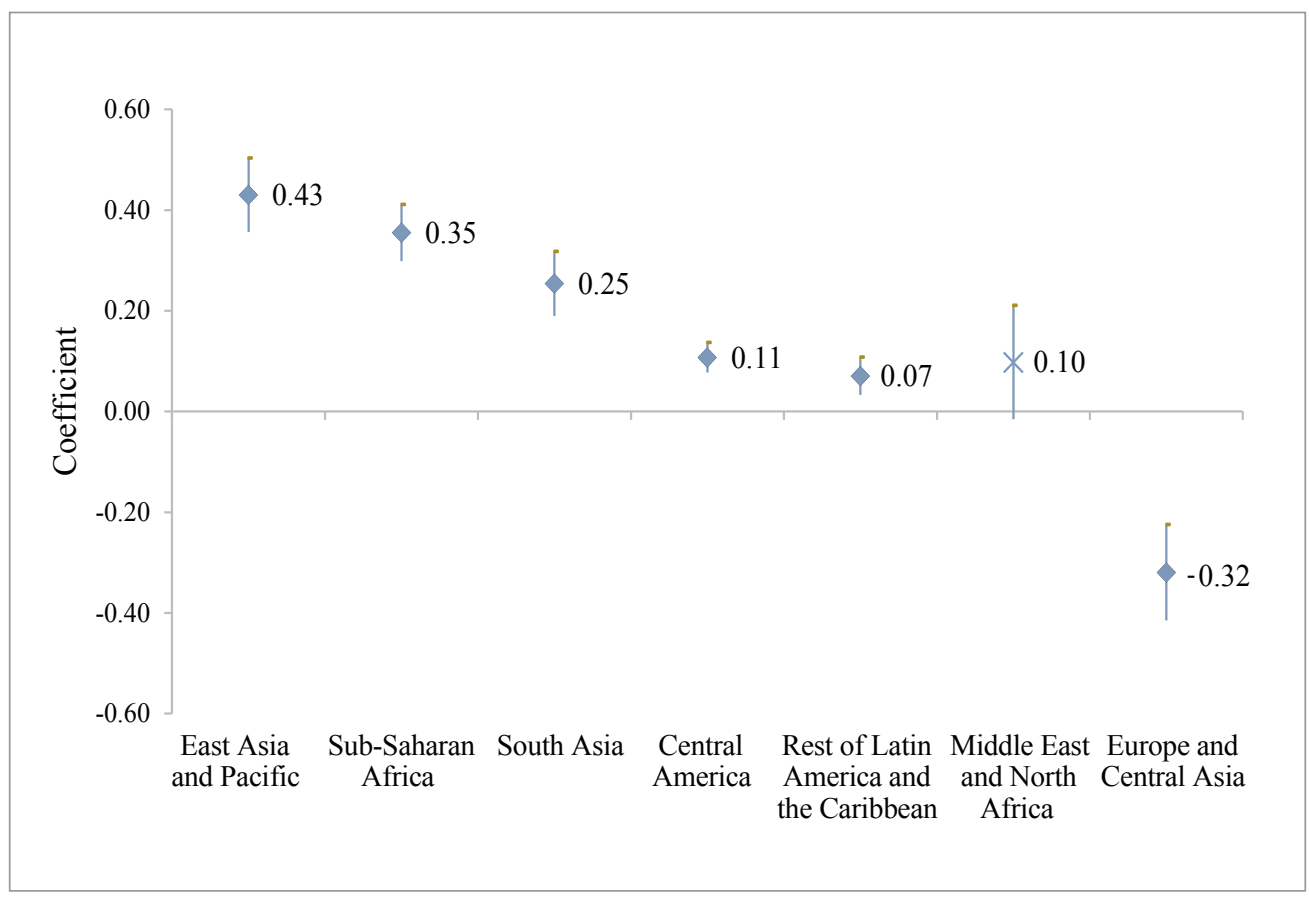

(Notes) (i) This figure shows the $95 \%$ confidence intervals of the price raising impact of TBT regulations by region.

(ii) The underlying coefficients are computed as the sum of the free-standing coefficient and the respective interaction term.

(iii) The level of significance is computed by a Wald test applied to this computation.

(iv) The point estimate is denoted by an $X$ when the coefficient is not statistically different to zero.

TBTs, on the other hand, do not have a significant effect on prices in the Central American region as shown in Figure 6. This is in contrast to the estimated positive impact computed for the rest of the Latin America and Caribbean region. We also find that TBTs have no impact on border prices in Sub-Saharan Africa whereas the South Asian region experiences a negative price effect that is equivalent to a subsidy of $32 \%$. 
Figure 5. Price-raising effect of technical barriers to trade measures

(World regions)

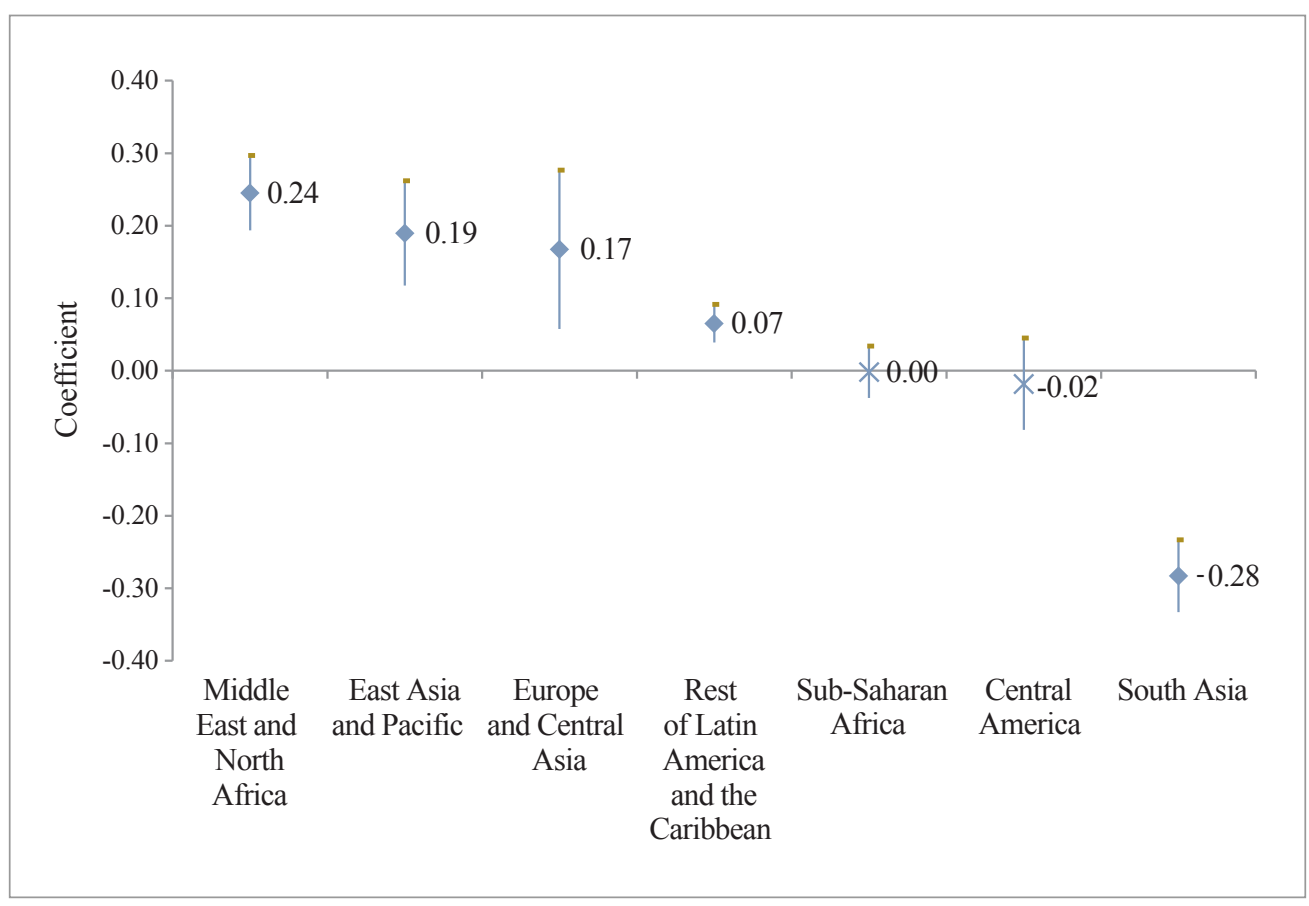

(Notes) (i) This figure shows the 95\% confidence intervals of the price raising impact of TBT regulations by region.

(ii) The underlying coefficients are computed as the sum of the free-standing coefficient and the respective interaction term.

(iii) The level of significance is computed by a Wald test applied to this computation.

(iv) The point estimate is denoted by an $X$ when the coefficient is not statistically different to zero.

In order to decompose the impact of SPS measures on each country in the Central American region, we interact country specific dummies with SPS dummies in specification 3. Results are presented in Appendix 3 and graphically depicted in Figure 7. The impact of SPS measures on prices varies widely between the five countries in Central America. SPS measures are found to have no impact on prices in Honduras and Nicaragua and have the largest price effect in Guatemala with an AVE of 55\%. The AVEs in El Salvador and Costa Rica are $23 \%$ and $6 \%$, respectively. 


\section{Figure 6. Price-raising effect of sanitary and phytosanitary measures}

(Central America)

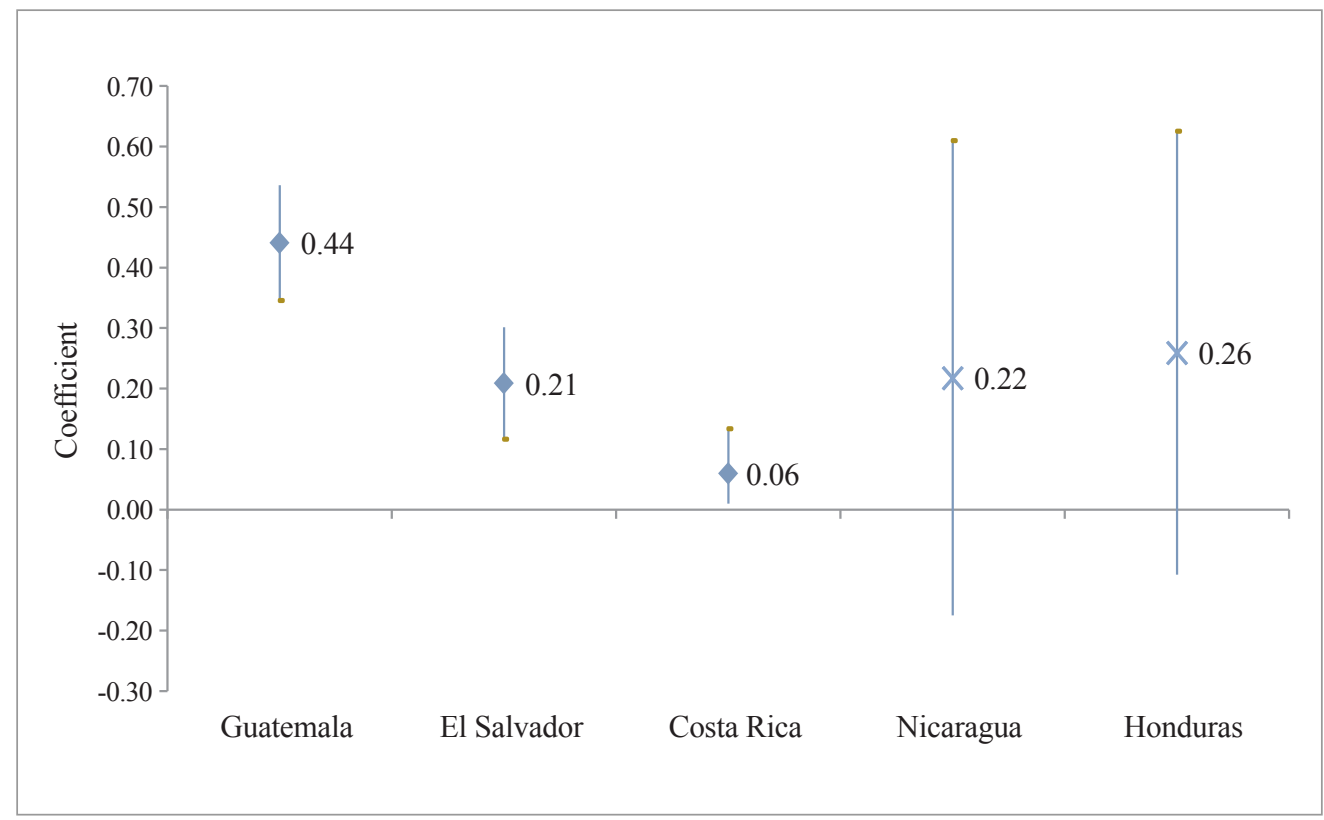

(Notes) (i) This figure shows the $95 \%$ confidence intervals of the price raising impact of SPS regulations by Central American country.

(ii) The underlying coefficients are computed as the sum of the free-standing coefficient and the respective interaction term.

(iii) The level of significance is computed by a Wald test applied to this computation.

(iv) The point estimate is denoted by an $X$ when the coefficient is not statistically different to zero.

(Source) Authors' calculations.

\section{SPS Measures and Poverty in Guatemala}

This section concentrates on the impact of SPS measures on domestic prices and, ultimately, on urban poverty in Guatemala. We focus our analysis on those products for which SPS measures in general, and registration requirements in particular, are especially challenging for traders in the region. These products are bread and pastries, beef, chicken 
meat, and dairy products. ${ }^{7}$ This section estimates AVEs of SPS measures for these products and then presents scenarios of their partial and total removal. Specifically, we offer a preliminary analysis of the direct impact of a reduction in domestic prices due to the streamlining of SPS measures on urban poverty levels.

The principle behind our calculation of changes in poverty due to a reduction or elimination of NTMs is as follows. For urban households, price-raising NTMs increase the cost of goods purchased, thereby acting as a tax, which should be balanced by the reduction of some externality. Without experimental evidence on the willingness to pay for the reduction of this negative externality, we can only estimate the tax side (the cost, but not the benefit). This value constitutes a lower bound on the social benefit (for example a reduction in mortality or disease risks brought about by the measure) which would be required to justify the presence of the NTM.

\section{A. Price-raising effect}

We estimate the price-raising effect of SPS measures by employing the empirical framework explained in Section III. Specifically, we use interaction terms in our crosscountry regression to estimate how different the effects of Guatemalan SPS measures, applied to our selected set of products, are from the average effect across countries and products. We then use Equation (8) to compute ad-valorem equivalents. Table 5 shows the results along with the list of the different NTMs, at the highest level of disaggregation, that importers need to comply with in order to import these products into the Guatemalan market.

\footnotetext{
${ }^{7}$ Consultations with the private sector in the region were undertaken in 2012. The cost of complying with SPS regulations for these four products was identified as one of the main hurdles to regional integration.
} 
Table 5. Influence on the selected products in Guatemala

\begin{tabular}{|c|c|c|}
\hline & Beef & Bread and Pastry \\
\hline & Sanitary and Phytosanitary Measures & Sanitary and Phytosanitary Measures \\
\hline & $\begin{array}{l}\text { A140 Special Authorization requirement } \\
\quad \text { for SPS reasons } \\
\text { A150 Registration requirements for importers } \\
\text { A310 Labelling requirements } \\
\text { A330 Packaging requirements } \\
\text { A420 Hygienic practices during production } \\
\text { A640 Storage and transport conditions } \\
\text { A810 Product registration requirements } \\
\text { A820 Testing requirement } \\
\text { A830 Certification requirement } \\
\text { A840 Inspection requirement }\end{array}$ & $\begin{array}{l}\text { A140 Special Authorization requirement } \\
\quad \text { for SPS reasons } \\
\text { A150 Registration requirements for importers } \\
\text { A310 Labelling requirements } \\
\text { A330 Packaging requirements } \\
\text { A810 Product registration requirements } \\
\text { A830 Certification requirement }\end{array}$ \\
\hline AVE & $68.4 \%$ & $51.4 \%$ \\
\hline
\end{tabular}

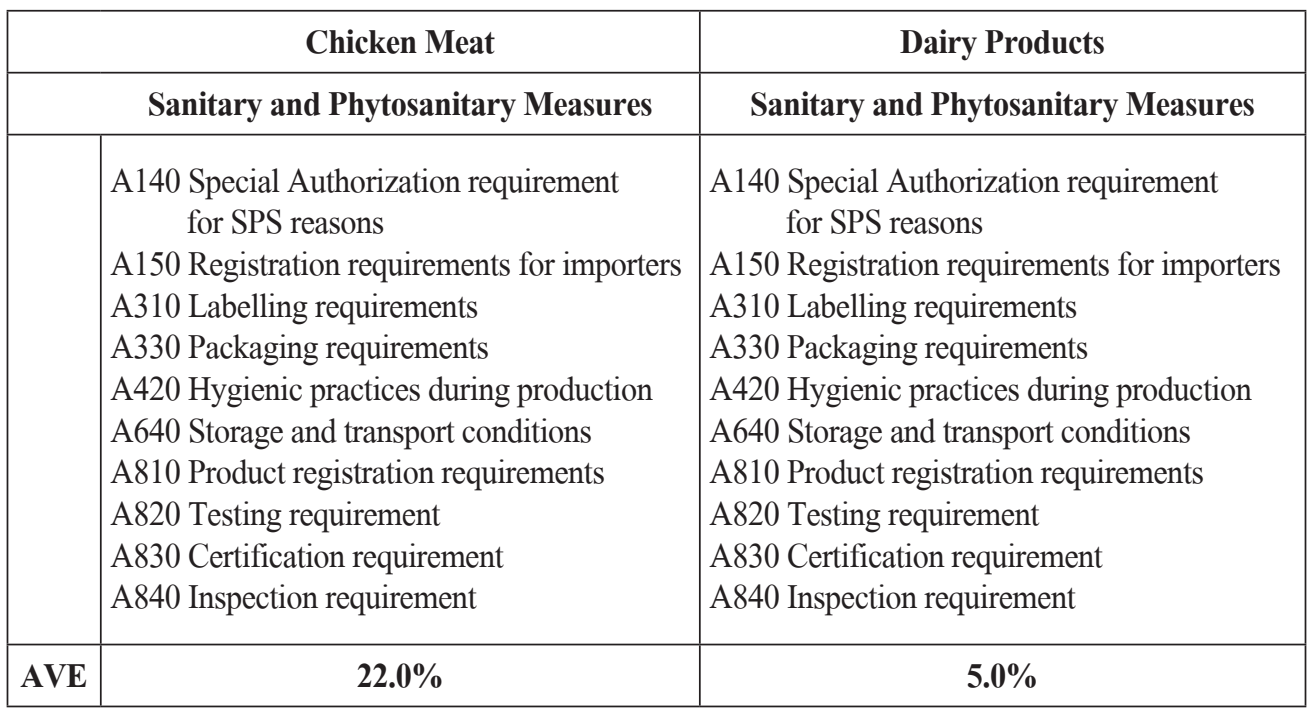

(Notes) (i) This table lists the SPS measures which apply to the selected products. SPS ad-valorem equivalents are statistically significant at least at the $10 \%$ level.

(ii) The HS codes associated with each product are as follows. Beef: 0201, 0202, 0206, 1502. Bread and Pastry: 1905. Chicken meat: 0207. Dairy products: 0401, 0402, 0403, 0404, 0405.

(Source) Authors' computation.

The results confirm that registration requirements for SPS reasons, the so-called sanitary registries, are a measure affecting trade in Guatemala. Only Kenya and Mauritius apply these types of measures as broadly as Guatemala, shown in Appendix 1. Other 
regulations, such as labeling and packaging requirements, are also imposed on these goods. The impact of SPS measures varies greatly across these four products. According to our estimation, the average increase in the Guatemalan domestic price of beef due to SPS measures is equivalent to an ad-valorem tariff of $68.4 \%$. This seems consistent with the perception of the Guatemalan beef market as quite closed to regional exporters, especially from Nicaragua. The AVE for the SPS measures facing bread and pastry, chicken meat, and dairy products are $51.4 \%, 22.0 \%$ and $5.0 \%$, respectively.

\section{B. Household expenditure}

We now explore the implications of our results for the cost of living across the income distribution in Guatemala. To do this, we combine our estimated AVEs with household expenditure data from the 2011 Guatemalan Household Survey (HHS) and calculate the budget share of these products by quintiles of the income distribution. Budget shares are the percentage of total annual income by household spent on the consumption of each good. Results are presented in Table 6 and as expected, given the essential nature of these items, the percentage of total income spent on them decreases with household income. Therefore, any policy aimed at streamlining NTMs would mainly benefit the poorest sector of the population in Guatemala.

Table 6. Households' budget shares of selected products

(Guatemala)

(By income quintiles, \%)

\begin{tabular}{|c|c|c|c|c|c|}
\hline Products & Q1 & Q2 & Q3 & Q4 & Q5 \\
\hline Beef & 1.18 & 0.90 & 0.71 & 0.57 & 0.35 \\
\hline Bread and Pastries & 1.04 & 0.96 & 0.85 & 0.69 & 0.38 \\
\hline Chicken Meat & 1.30 & 1.03 & 0.83 & 0.70 & 0.46 \\
\hline Diary Products & 0.59 & 0.50 & 0.41 & 0.36 & 0.24 \\
\hline Total & $\mathbf{4 . 1 1}$ & $\mathbf{3 . 3 9}$ & $\mathbf{2 . 8 0}$ & $\mathbf{2 . 3 1}$ & $\mathbf{1 . 4 3}$ \\
\hline
\end{tabular}

(Note) Each type of product is mapped to a group of goods in the HHS as follows: Beef (carne de cerdo con y sin hueso and carne de res sin y con hueso), bread and pastries (pan de rodaja, pan dulce, pan frances), chicken meat (carne de pollo o gallina, viceras de pollo o gallina), and dairy products (leche liquida, queso fresco o duro).

(Source) Authors' computation using the Guatemala 2011 HHS. 


\section{Impact of streamlining sanitary and phytosanitary measures on poverty rates}

We now look at the hypothetical cases of the total and partial removal of SPS measures on our set of selected products and analyze the impact of these changes on poverty rates in Guatemala. We follow Porto (2010) in this analysis. Using the 2011 HHS, we calculate the Head Count (HC) ratio, defined as the fraction of the population with an income below the poverty line $z$. That is,

$$
H C=\frac{1}{N} \sum_{i} 1\left\{y^{i}<z\right\}
$$

where $N$ is total population, $y^{i}$ is income, and $1\{\quad\}$ is an indicator function that takes value 1 if the $y^{i}<z$ within brackets is true. Guatemala uses two poverty lines. The extreme poverty line is the cost of purchasing the poverty consumption basket, which includes food items that satisfy a minimum caloric and energetic intake. ${ }^{8}$ This value corresponds to 4,380 quetzales per person annually, i.e., around 560 US dollars. The general poverty line includes some expenditure for non-food items and is set to 9,030.93 quetzales per person, annually, i.e., around 1,150 US dollars. ${ }^{9}$

The poverty analysis requires a comparison of the proportion of individuals in poverty before and after the policy scenarios. Given a poverty line $z$, the head count is given by $F(z)$, where $F(z)$ is the observed cumulative distribution function of income before the shock. The head count is defined as

$$
H C=\int_{0}^{z} f(y) d y
$$

where $f($.$) is the density of per equivalent adult income associated to F($.$) . Let t^{*}$ be the policy parameter (partial or total removal of NTMs) that represents the level of protection. Differentiating with respect to $t^{*}$, we get:

$$
\frac{\partial}{\partial t *} H C=f(z) \frac{\partial z}{\partial t *}+\int_{0}^{z} \frac{\partial}{\partial t *} f(y) d y
$$

\footnotetext{
${ }^{8}$ These values correspond to 2,246 calories in urban areas and 2,362 in rural areas.

${ }^{9}$ Guatemala does not compute different poverty lines for rural and urban households.
} 
A policy shock that changes the ad-valorem equivalent ( $\left.t^{*}\right)$ has two effects on poverty: a change in the poverty line, as a variation in $t^{*}$ affects consumer prices and, therefore, the cost of purchasing the poverty bundle, and a change in the distribution of income. For the sake of simplicity, this study focuses on the first effect, i.e., the direct effect on the poverty line.

The poverty line can also be defined as $z=\sum_{g} p_{g} q_{g}$, where $p_{g}$ is the price of good $g$, and $q_{g}$ is the quantity determined in the construction of the poverty line. Holding quantities constant, the change in the (log) poverty line caused by a change in price of good $g$ is given by:

$$
\Delta \ln z=\alpha_{g} \Delta \ln p_{g}\left(t^{*}\right)
$$

where $\alpha_{g}$ is the weight attached to good $g$ and $\Delta \ln p_{g}\left(t^{*}\right)$ is the price-raising effect of NTMs. We update the poverty line by summing Equation (12) across all products affected by the policy shock.

$$
\hat{\Delta} \ln z=\sum \widehat{\alpha_{g}} \Delta \ln p_{g}\left(t^{*}\right)
$$

We estimate the weights, $\widehat{\alpha_{g}}$, using the average budget share spent on food products by households in the second quintile of the distribution.

We explore two policy shocks associated with an attempt to streamline SPS measures in Guatemala. The first is the unrealistic case of a total elimination of the costs of complying with SPS measures for the selected products, i.e., $\mathrm{AVE}=0$. The second is the case where efforts to streamline SPS measures reduce the AVE by half. Given that we abstract from the impact on production (the change in income distribution), we only consider the impact on poverty for urban households. The underlying assumption is that the price change brought about by streamlining SPS measures decreases prices but leaves income distribution unchanged because urban households are employed in economic activities outside the agricultural sector. Finally, since we are not allowing the nontradable prices to adjust, we center the discussion on the impact of our policy scenarios on extreme poverty rates, although we also report the results for general poverty rates. Table 7 compares the proportion of the population living in poverty in year 2011 and after streamlining SPS measures. 
Table 7. Poverty impact of streamlining sanitary and phytosanitary measures

(Guatemala)

(Urban Poverty Rates)

\begin{tabular}{|c|c|c|c|}
\hline \multirow{2}{*}{ Poverty Line } & \multirow{2}{*}{ Initial Poverty Rate } & \multicolumn{2}{|c|}{ Ex-Post Poverty Rates } \\
\cline { 3 - 4 } & & Total & Partial \\
\hline Extreme & 5.07 & 4.59 & 4.91 \\
\hline Total & 34.97 & 32.66 & 33.98 \\
\hline
\end{tabular}

(Note) This table shows the poverty impact of total and partial elimination of SPS measures applied to beef, bread and pastries, chicken meat, and dairy products in Guatemala.

(Source) Authors' computation using the 2011 Guatemalan HHS.

The main finding is that an effort to streamline NTMs in Guatemala would likely reduce poverty. Specifically, working towards rationalizing the processes related to SPS measures affecting beef, bread and pastries, chicken meat, and dairy products would reduce domestic prices and, thus, make the basic consumption basket more affordable. Our computations suggest that streamlining the key SPS measures affecting these products by, for example, reducing the cost and time required to obtain sanitary registries, could reduce the urban extreme poverty rate from $5.07 \%$ to $4.91 \%$. This would mean lifting approximately 20,000 people out of extreme poverty in urban areas in Guatemala. Figure 7 depicts the left shift in the poverty line due to a scenario of total elimination of the cost of complying with SPS measures in our products. The dotted line is the new extreme poverty line under total reduction of price-controls in Guatemala. 


\section{Figure 7. Poverty effect of streamlining sanitary and phytosanitary measures}

(Guatemala)

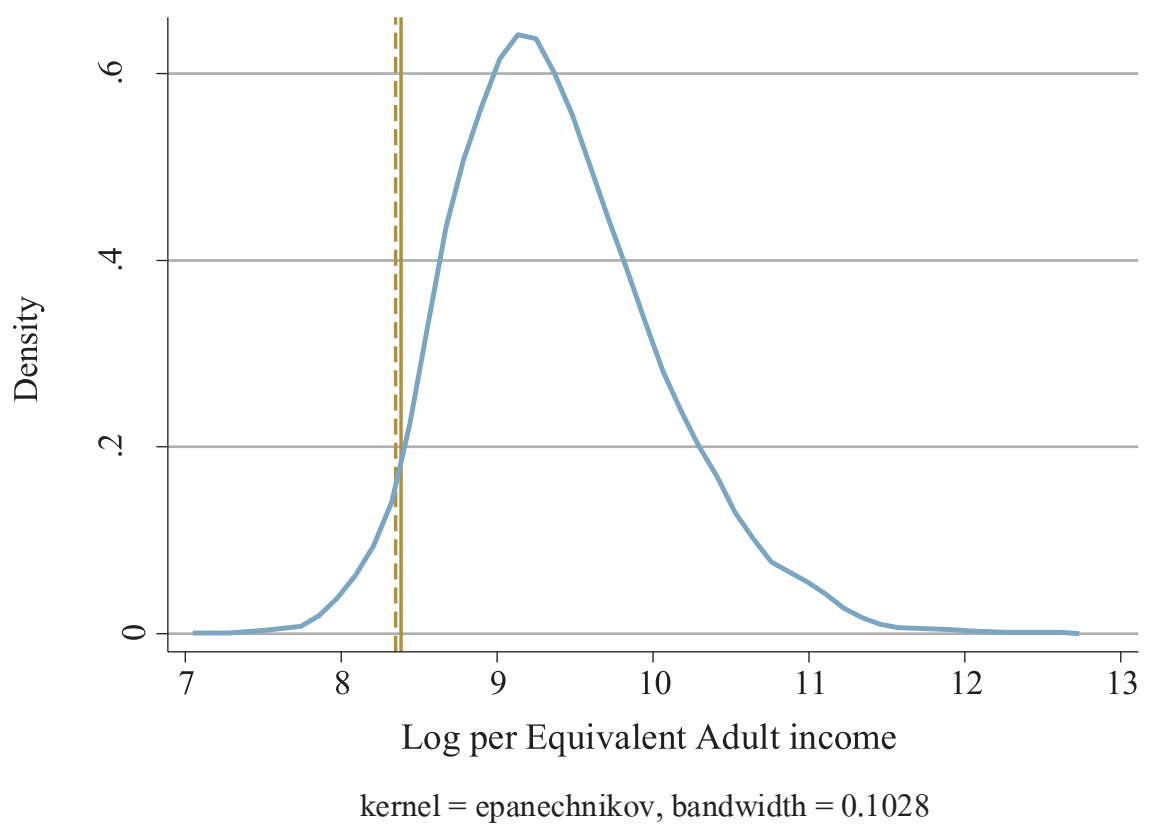

(Note) This figure shows the density function of per equivalent adult income and two poverty lines (the vertical lines). The dashed poverty line corresponds to the situation after the hypothetical elimination of SPS measures in Guatemala.

(Source) Authors' computation using the 2011 Guatemalan HHS.

\section{Concluding Remarks}

With the decline in traditional trade barriers initiated by the Dominican RepublicCentral America Free Trade Agreement (DR-CAFTA), NTMs are increasingly viewed as a key trade policy issue in Central America. Yet, despite anecdotal evidence that borders remain thick, there is little quantitative understanding of the incidence of NTMs in the region. This paper provides the first attempt to look at the incidence of technical NTMs, i.e., SPS and TBT regulations, and to estimate their impact on border prices 
in Central America. It also assesses the impact of SPS measures on the border prices of important consumption products in Guatemala and estimates the poverty impact of streamlining key SPS measures affecting them.

While Central America has the lowest prevalence of technical regulations among other world regions, we found significant heterogeneity in the use of technical NTMs across countries in the region. El Salvador uses them most intensively, followed by Guatemala, Nicaragua, Costa Rica, and Honduras. The average impact of SPS measures on border prices across the region is equivalent to an ad-valorem tariff of $11.6 \%$. This effect is particularly important for products that are significant for the consumption basket of the poor in Guatemala: beef, chicken meat, bread, and dairy products. The equivalent ad-valorem tariffs of SPS regulation for these products are estimated to be $68.4 \%, 51.4 \%, 22.0 \%$, and 5.0\%, respectively. Our estimates indicate that policies aimed at streamlining SPS measures by, for example, reducing the cost and time required to obtain sanitary registries, will likely translate to a reduction of urban extreme poverty rates of 16 basis points.

These findings have strong policy implications for deepening regional integration, harnessing private sector competitiveness, and poverty alleviation in Central America. We make the following suggestions for policy dialogue at the regional level aimed at streamlining trade related regulations.

- Better dissemination of the current laws and regulations about import and export procedures to the wider public, particularly the business community, would alleviate informational asymmetries that increase the cost of doing business in Central America.

- A well-organized regional reporting and monitoring mechanism would help identifying regulatory problems and potential inconsistencies across countries' regimes in a timely fashion.

- Setup a regional regulatory body that oversees and discusses the regional regulatory framework affecting trade.

- Streamline sanitary registrations for processed food and beverages. Even though there is a mutual recognition agreement in the region, the implementation process is stymied by regulatory and technical constraints. A solution that could make great strides is the formation of a regional, electronic database that centralizes documentation about the credentials that each firm submits to meet the sanitary registration requirements. 


\section{References}

Aisbett, Emma and Lee M. Pearson. "Environmental and Health Protections, or New Protectionism? Determinants of SPS Notifications by WTO Members.” Working Paper, Crawford School of Public Policy, Australian National University, Canberra. (2012).

Akerlof, George A. "The Market for "Lemons": Quality Uncertainty and the Market Mechanism." The Quarterly Journal of Economics 84, no. 3 (1970): 488-500.

Andriamananjara, Soamiely, Judith M. Dean, Robert Feinberg, Michael J. Ferrantino, Rodney Ludema and Marinos Tsigas. "The Effects of Non-Tariff Measures on Prices, Trade, and Welfare: CGE Implementation of Policy-Based Price Comparisons." Working Paper, United States International Trade Commission, Washington DC. (2004).

Beghin, John C. and Jean-Christophe Bureau. "Quantitative Policy Analysis of Sanitary, Phytosanitary and Technical Barriers to Trade." Economic Internationale 3, no. 87 (2001):107-130.

Beghin, John C., Anne-Célia Disdier and Stéphan Marette. "Trade Restrictiveness Indices in Presence of Externalities: An Application to Non-Tariff Measures." Working Papers, Department of Economics, Iowa State University, Iowa. (2013).

Berthou, Antoine and Charlotte Emlinger. "The Trade Unit Values Database.” Working Paper, CEPII, Paris. (2011).

Bradford, Scott. "Paying the Price: Final Goods Protection in OECD Countries." The Review of Economics and Statistics 85, no. 1 (2003): 24-37.

Cadot, Olivier and Julien Gourdon. "Assessing the Price-Raising Effect of Non-Tariff Measures in Africa." Journal of African Economies 23, no. 4 (2014): 425-463.

Cadot, Olivier and Julien Gourdon. "Do Non-tariff Measures Raise Prices? Evidence for Trade Unit Values.” Mimeo, University of Lausanne and CEPII. (2012).

Cadot, Olivier and Mariem Malouche, eds. Non-Tariff Measures. A Fresh Look at Trade Policy's New Frontier. Washington, DC: World Bank, 2012. 
Calvin, Linda and Barry Krissoff. "Technical Barriers to Trade: A Case Study of Phytosanitary Barriers and U.S.-Japanese Apple Trade." Journal of Agricultural and Resource Economics 23, no. 2 (1998): 351-366.

Cato James C., W. Steven Otwell, and Agnés Saborío Coze. "Nicaragua’s Shrimp Subsector: Developing a Production Capacity and Export Market during Rapidly Changing Worldwide Safety and Quality Regulations.” Working Paper, World Bank, Washington DC. (2005).

Chemingui, Mohamed Abdelbasset and Sebastien Dessus. "Assessing Non-Tariff Barriers in Syria.” Journal of Policy Modeling 30, no. 5 (2008): 917-928.

Crivelli, Pramila and Jasmin Gröschl. "The Impact of Sanitary and Phytosanitary Measures on Market Entry and Trade Flows.” Working Paper, Ifo, Munich. (2012).

Disdier, Anne-Célia, Lionel Fontagné and Mondher Mimouni. "The Impact of Regulations on Agricultural Trade: Evidence from the SPS and TBT Agreements." American Journal of Agricultural Economics 90, no. 2 (2008): 336-350.

Fischer, Ronald and Pablo Serra. "Standards and Protection." Journal of International Economics 52, no. 2 (2000): 377-400.

Fontagné, Lionel, Mondher Mimouni and Jean-Michel Pasteels. "Estimating the Impact of Environmental SPS and TBT on International Trade." Integration and Trade Journal 22, no.3 (2005): 7-37.

Ganslandt, Mattias and James R. Markusen. "Standards and Related Regulations in International Trade: A Modeling Approach.” Working Paper, National Bureau of Economic Research, Massachusetts. (2001).

Gordillo, Darwin Marcelo, Aiga Stokenberga and Jordan Schwartz. "Understanding the Benefits of Regional Integration to Trade: The Application of a Gravity Model to the Case of Central America.” Working Paper, World Bank, Washington DC. (2010).

Henson, Spencer, Rupert Loader, Alan Swinbank, Maury Bredahl, and Nicole Lux. Impact of Sanitary and Phytosanitary Measures on Developing Countries. Reading: University of Reading, 2000.

INCAE Business School. "Registros Sanitarios de Alimentos y Bebidas en Centroamérica." Mimeo, INCAE Business School. (2013). 
Kee, Hiau Looi, Alessandro Nicita and Marcelo Olarreaga. "Estimating Trade Restrictiveness Indices.” Economic Journal 119, no. 534 (2009): 172-199.

Porto, Guido. "International Market Access and Poverty in Argentina." Review of International Economics 18, no. 2 (2010): 396-407.

Portugal-Perez, Alberto, José-Daniel Reyes and John S. Wilson. "Beyond the Information Technology Agreement: Harmonization of Standards and Trade in Electronics." The World Economy 33, no. 12 (2010): 1870-1897.

Reyes, José-Daniel. "International Harmonization of Product Standards and Firm Heterogeneity in International Trade." Working Paper, World Bank, Washington DC. (2011).

Reyes, José-Daniel. "The Pro-Competitive Effect of International Harmonization of Product Standards." In Non-Tariff Measures. A Fresh Look at Trade Policy's New Frontier, edited by Olivier Cadot and Mariam Malouche, 167-186. Washington DC: World Bank, 2012.

Shirotori, Miho, Bolormaa Tumurchudur, and Olivier Cadot.. Revealed Factor Intensity Indices at the Product Level. New York and Geneva: United Nations, 2010.

UNCTAD. Non-Tariff Measures: Evidence from Selected Developing Countries and Future Research Agenda. New York and Geneva: UNCTAD, 2010.

UNCTAD. Classification of Non-Tariff Measures. Geneva: UNCTAD, 2012.

Walkenhorst, Peter and Tadashi Yasui. "Quantitative Assessment of the Benefits of Trade Facilitation." In Overcoming Border Bottlenecks: The Costs and Benefits of Trade Facilitation, edited by OECD, 19-49. Paris: OECD, 2009.

WTO. World Trade Report, 2012, Trade and Public Policies: A Closer Look at NonTariff Measures in the 21st Century. Geneva: WTO, 2012. 


\section{Appendix 1: Registration requirements for importers due to sanitary and phytosanitary reasons}

(A150)

(Coverage Ratios, \%)

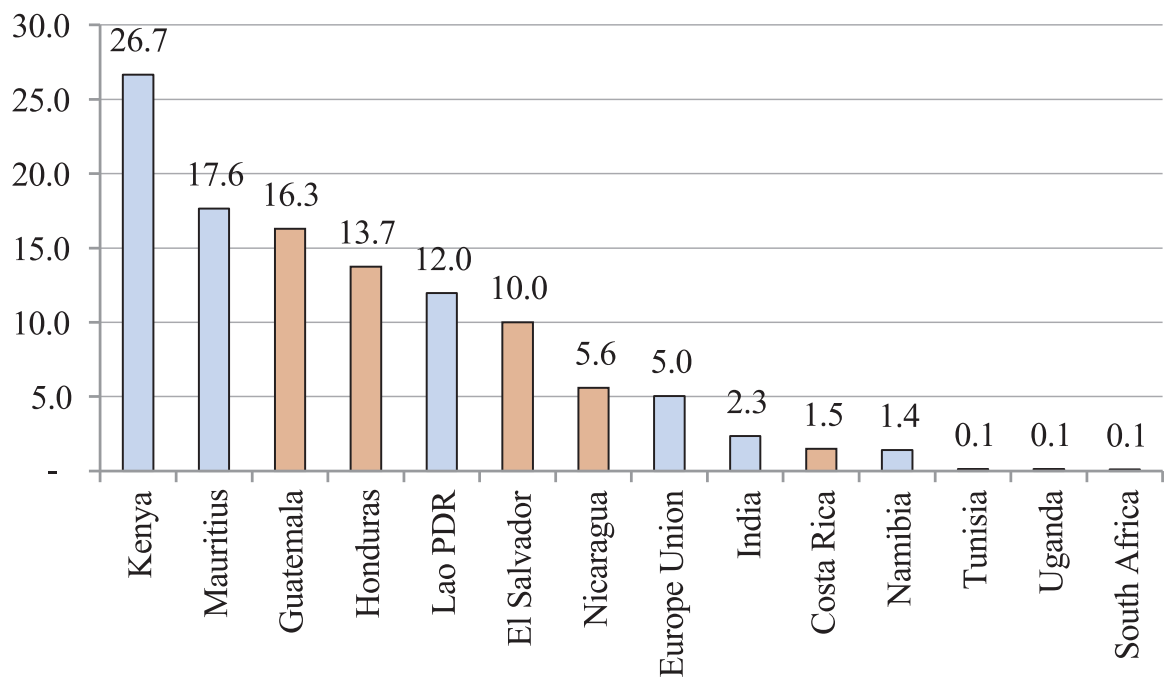

(Note) This figure shows the coverage ratio of registration requirements of importers due to SPS reasons across all countries for which data are available.

(Source) Authors' computation. 


\section{Appendix 2: Price-raising effect of non-tariff measures}

\begin{tabular}{|c|c|c|c|c|c|c|c|}
\hline Variables & $\begin{array}{c}\text { Central } \\
\text { America }\end{array}$ & $\begin{array}{c}\text { America } \\
\text { Rest of Latin } \\
\text { America and } \\
\text { the Caribbean }\end{array}$ & $\begin{array}{c}\text { Sub- } \\
\text { Saharan }\end{array}$ & $\begin{array}{c}\text { East Asia } \\
\text { and }\end{array}$ & $\begin{array}{c}\text { Europe and } \\
\text { Central Asia }\end{array}$ & $\begin{array}{c}\text { Middel East } \\
\text { and North } \\
\text { Africa }\end{array}$ & $\begin{array}{c}\text { South South } \\
\text { Asia }\end{array}$ \\
\hline SPS & $\begin{array}{c}0.093^{* * *} \\
(0.013)\end{array}$ & $\begin{array}{c}0.123 * * * \\
(0.011)\end{array}$ & $\begin{array}{c}0.258^{* * *} \\
(0.011)\end{array}$ & $\begin{array}{c}0.142 * * * \\
(0.012)\end{array}$ & $\begin{array}{c}0.222 * * * \\
(0.011)\end{array}$ & $\begin{array}{c}0.181^{* * *} \\
(0.011)\end{array}$ & $\begin{array}{c}0.203 * * * \\
(0.012)\end{array}$ \\
\hline $\begin{array}{r}\text { XRegion } \\
\text { Dummy }\end{array}$ & $\begin{array}{c}0.014 \\
(0.020)\end{array}$ & $\begin{array}{c}-0.053 * * \\
(0.021)\end{array}$ & $\begin{array}{c}0.096^{* * *} \\
(0.029)\end{array}$ & $\begin{array}{c}0.287^{* * *} \\
(0.039)\end{array}$ & $\begin{array}{c}-0.542 * * * \\
(0.049)\end{array}$ & $\begin{array}{c}0.083 \\
(0.059)\end{array}$ & $\begin{array}{c}0.051 \\
(0.035)\end{array}$ \\
\hline$T B T$ & $\begin{array}{c}0.007 \\
(0.009)\end{array}$ & $\begin{array}{c}-0.032^{* * *} \\
(0.011)\end{array}$ & $\begin{array}{c}-0.065^{* * *} \\
(0.010)\end{array}$ & $\begin{array}{c}-0.050^{* * *} \\
(0.009)\end{array}$ & $\begin{array}{c}-0.022^{* *} \\
(0.009)\end{array}$ & $\begin{array}{c}-0.038^{* * *} \\
(0.009)\end{array}$ & $\begin{array}{c}0.029 * * * \\
(0.010)\end{array}$ \\
\hline $\begin{array}{r}\text { X Region } \\
\text { Dummy }\end{array}$ & $\begin{array}{l}-0.026 \\
(0.034)\end{array}$ & $\begin{array}{c}0.097 * * * \\
(0.017)\end{array}$ & $\begin{array}{c}0.064^{* * *} \\
(0.020)\end{array}$ & $\begin{array}{c}0.239 * * * \\
(0.038)\end{array}$ & $\begin{array}{c}0.189 * * * \\
(0.056)\end{array}$ & $\begin{array}{c}0.283^{* * *} \\
(0.028)\end{array}$ & $\begin{array}{c}-0.312^{* * *} \\
(0.027)\end{array}$ \\
\hline $\begin{array}{l}\text { Region } \\
\text { Dummy }\end{array}$ & $\begin{array}{c}0.544^{* * *} * \\
(0.020)\end{array}$ & $\begin{array}{c}-0.675^{* * *} \\
(0.011)\end{array}$ & $\begin{array}{c}0.754^{* * *} \\
(0.015)\end{array}$ & $\begin{array}{c}-0.385^{* * *} \\
(0.016)\end{array}$ & $\begin{array}{c}0.818^{* * *} \\
(0.031)\end{array}$ & $\begin{array}{c}-0.324^{* * *} \\
(0.013)\end{array}$ & $\begin{array}{c}-0.087^{* * *} \\
(0.014)\end{array}$ \\
\hline $\log (G D P)$ & $\begin{array}{c}-0.036^{* * *} \\
(0.003)\end{array}$ & $\begin{array}{c}-0.079^{* * *} \\
(0.003)\end{array}$ & $\begin{array}{c}-0.055^{* * *} \\
(0.003)\end{array}$ & $\begin{array}{c}-0.090^{* * *} \\
(0.003)\end{array}$ & $\begin{array}{c}-0.086^{* * *} \\
(0.003)\end{array}$ & $\begin{array}{c}-0.088^{* * *} \\
(0.003)\end{array}$ & $\begin{array}{c}-0.084^{* * *} \\
(0.003)\end{array}$ \\
\hline Log (Distance) & $\begin{array}{c}0.144^{* * *} \\
(0.004)\end{array}$ & $\begin{array}{c}0.279 * * * \\
(0.003)\end{array}$ & $\begin{array}{c}0.097^{* * *} \\
(0.004)\end{array}$ & $\begin{array}{c}0.146^{* * *} \\
(0.004)\end{array}$ & $\begin{array}{c}0.186^{* * *} \\
(0.003)\end{array}$ & $\begin{array}{c}0.111^{* * *} \\
(0.003)\end{array}$ & $\begin{array}{c}0.154^{* * *} \\
(0.004)\end{array}$ \\
\hline $\log (H / L)$ & $\begin{array}{c}0.900 * * * \\
(0.014)\end{array}$ & $\begin{array}{c}0.958^{* * *} \\
(0.014)\end{array}$ & $\begin{array}{c}0.503^{* * *} \\
(0.013)\end{array}$ & $\begin{array}{c}0.785^{* * *} \\
(0.014)\end{array}$ & $\begin{array}{c}0.530^{* * *} \\
(0.013)\end{array}$ & $\begin{array}{c}0.603^{* * *} \\
(0.013)\end{array}$ & $\begin{array}{c}0.634^{* * *} \\
(0.014)\end{array}$ \\
\hline $\log (T / L)$ & $\begin{array}{c}-0.135^{* * *} \\
(0.004)\end{array}$ & $\begin{array}{c}-0.097^{* * *} \\
(0.004)\end{array}$ & $\begin{array}{c}-0.172 * * * \\
(0.004)\end{array}$ & $\begin{array}{c}-0.165^{* * *} \\
(0.004)\end{array}$ & $\begin{array}{c}-0.214^{* * *} \\
(0.005)\end{array}$ & $\begin{array}{c}-0.150^{* * *} \\
(0.004)\end{array}$ & $\begin{array}{c}-0.173^{* * *} \\
(0.004)\end{array}$ \\
\hline $\log (K / L)$ & $\begin{array}{c}0.291^{* * *} \\
(0.006)\end{array}$ & $\begin{array}{c}0.391^{* * *} \\
(0.005)\end{array}$ & $\begin{array}{c}0.480^{* * *} \\
(0.005)\end{array}$ & $\begin{array}{c}0.345^{* * *} \\
(0.005)\end{array}$ & $\begin{array}{c}0.381 * * * \\
(0.005)\end{array}$ & $\begin{array}{c}0.389^{* * *} \\
(0.005)\end{array}$ & $\begin{array}{c}0.370^{* * *} \\
(0.005)\end{array}$ \\
\hline Contiguity & $\begin{array}{c}-0.063^{* * *} \\
(0.007)\end{array}$ & $\begin{array}{c}0.147^{* * *} \\
(0.006)\end{array}$ & $\begin{array}{c}-0.051^{* * *} \\
(0.007)\end{array}$ & $\begin{array}{c}-0.089^{* * * *} \\
(0.007)\end{array}$ & $\begin{array}{c}-0.046^{* * *} \\
(0.007)\end{array}$ & $\begin{array}{c}-0.138^{* * *} \\
(0.006)\end{array}$ & $\begin{array}{c}-0.060 * * * \\
(0.007)\end{array}$ \\
\hline $\begin{array}{l}\text { Common Official } \\
\text { Language }\end{array}$ & $\begin{array}{c}0.152^{* * *} \\
(0.008)\end{array}$ & $\begin{array}{c}0.028^{* * *} \\
(0.008)\end{array}$ & $\begin{array}{c}-0.038^{* * *} \\
(0.007)\end{array}$ & $\begin{array}{c}0.121^{* * *} \\
(0.008)\end{array}$ & $\begin{array}{c}0.144^{* * *} \\
(0.008)\end{array}$ & $\begin{array}{c}0.117^{* * * *} \\
(0.008)\end{array}$ & $\begin{array}{c}0.103^{* * *} \\
(0.008)\end{array}$ \\
\hline $\begin{array}{l}\text { Common Ethnical } \\
\text { Language }\end{array}$ & $\begin{array}{c}-0.099 * * * \\
(0.008)\end{array}$ & $\begin{array}{c}0.012 \\
(0.008)\end{array}$ & $\begin{array}{c}-0.073^{* * *} \\
(0.008)\end{array}$ & $\begin{array}{c}-0.069 * * * \\
(0.008)\end{array}$ & $\begin{array}{c}-0.070^{* * *} \\
(0.008)\end{array}$ & $\begin{array}{c}-0.086^{* * *} \\
(0.008)\end{array}$ & $\begin{array}{c}-0.085^{* * *} \\
(0.008)\end{array}$ \\
\hline $\begin{array}{l}\text { Common } \\
\text { Colonizer }\end{array}$ & $\begin{array}{c}0.043^{* * *} \\
(0.009)\end{array}$ & $\begin{array}{l}-0.016^{*} \\
(0.010)\end{array}$ & $\begin{array}{c}-0.064^{* * *} \\
(0.009)\end{array}$ & $\begin{array}{c}-0.023^{* *} \\
(0.009)\end{array}$ & $\begin{array}{c}-0.036^{* * *} \\
(0.010)\end{array}$ & $\begin{array}{c}-0.042^{* * *} \\
(0.010)\end{array}$ & $\begin{array}{c}0.056^{* * *} \\
(0.009)\end{array}$ \\
\hline Constant & $\begin{array}{c}2.365^{* *} \\
(0.096) \\
\end{array}$ & $\begin{array}{c}1.301^{* * *} \\
(0.095) \\
\end{array}$ & $\begin{array}{c}1.656^{* * *} \\
(0.098)\end{array}$ & $\begin{array}{c}3.479 * * * \\
(0.102)\end{array}$ & $\begin{array}{c}3.100^{* * *} \\
(0.101)\end{array}$ & $\begin{array}{c}3.679 * * * \\
(0.100)\end{array}$ & $\begin{array}{c}3.259^{* * *} \\
(0.099)\end{array}$ \\
\hline Exporter FE & Yes & Yes & Yes & Yes & Yes & Yes & Yes \\
\hline Product FE & Yes & Yes & Yes & Yes & Yes & Yes & Yes \\
\hline Observations & $1,922,527$ & $1,922,527$ & $1,922,527$ & $1,922,527$ & $1,922,527$ & $1,922,527$ & $1,922,527$ \\
\hline$R$-squared & 0.591 & 0.600 & 0.598 & 0.589 & 0.590 & 0.589 & 0.589 \\
\hline
\end{tabular}




\section{Appendix 3: Price-raising effect of sanitary and phytosanitary measures}

\begin{tabular}{|c|c|c|c|c|c|}
\hline Variables $\quad$ Region & Costa Rica & El Salvador & Guatemala & Nicaragua & Honduras \\
\hline SPS & $\begin{array}{l}0.183 * * * \\
(0.00978)\end{array}$ & $\begin{array}{l}0.198 * * * \\
(0.00977)\end{array}$ & $\begin{array}{l}0.183 * * * \\
(0.00962)\end{array}$ & $\begin{array}{c}0.128 * * * \\
(0.0102)\end{array}$ & $\begin{array}{c}0.176^{* * *} \\
(0.0101)\end{array}$ \\
\hline X Country Dummy & $\begin{array}{c}-0.124^{* * *} \\
(0.0382)\end{array}$ & $\begin{array}{c}0.041^{* * *} \\
(0.0486)\end{array}$ & $\begin{array}{c}0.257 * * * \\
(0.0491)\end{array}$ & $\begin{array}{c}0.090 \\
(0.200)\end{array}$ & $\begin{array}{c}0.083 \\
(0.187)\end{array}$ \\
\hline Country Dummy & $\begin{array}{c}-0.420 * * * \\
(0.0163)\end{array}$ & $\begin{array}{c}0.456 * * * \\
(0.0161)\end{array}$ & $\begin{array}{l}1.172 * * * \\
(0.0197)\end{array}$ & $\begin{array}{c}0.507 * * \\
(0.199)\end{array}$ & $\begin{array}{l}0.0608 \\
(0.186)\end{array}$ \\
\hline $\log (G D P)$ & $\begin{array}{c}-0.0949 * * * \\
(0.00308)\end{array}$ & $\begin{array}{c}-0.0775^{* * *} \\
(0.00311)\end{array}$ & $\begin{array}{c}-0.0633 * * * \\
(0.00302)\end{array}$ & $\begin{array}{c}-0.0738^{* * *} \\
(0.00314)\end{array}$ & $\begin{array}{c}-0.0818 * * * \\
(0.00314)\end{array}$ \\
\hline $\log ($ Distance $)$ & $\begin{array}{l}0.159 * * * \\
(0.00352)\end{array}$ & $\begin{array}{l}0.160 * * * \\
(0.00354)\end{array}$ & $\begin{array}{l}0.129 * * * \\
(0.00352)\end{array}$ & $\begin{array}{l}0.156^{* * *} * \\
(0.00352)\end{array}$ & $\begin{array}{l}0.158^{* * *} \\
(0.00353)\end{array}$ \\
\hline $\log (H / L)$ & $\begin{array}{c}0.702 * * * \\
(0.0131)\end{array}$ & $\begin{array}{c}0.681 * * * \\
(0.0132)\end{array}$ & $\begin{array}{l}1.042 * * * \\
(0.0152)\end{array}$ & $\begin{array}{c}0.738^{* * *} \\
(0.0131)\end{array}$ & $\begin{array}{c}0.698^{* * *} \\
(0.0130)\end{array}$ \\
\hline $\log (T / L)$ & $\begin{array}{c}-0.175^{* * *} \\
(0.00442)\end{array}$ & $\begin{array}{l}-0.152^{* * *} \\
(0.00421)\end{array}$ & $\begin{array}{l}-0.151^{* * *} \\
(0.00419)\end{array}$ & $\begin{array}{l}-0.165^{* * *} \\
(0.00428)\end{array}$ & $\begin{array}{c}-0.156^{* * *} \\
(0.00422)\end{array}$ \\
\hline $\log (K / L)$ & $\begin{array}{l}0.384^{* * *} \\
(0.00503)\end{array}$ & $\begin{array}{l}0.369 * * * \\
(0.00499)\end{array}$ & $\begin{array}{l}0.292 * * * \\
(0.00531)\end{array}$ & $\begin{array}{l}0.356^{* * *} \\
(0.00499)\end{array}$ & $\begin{array}{l}0.368^{* * *} \\
(0.00502)\end{array}$ \\
\hline Contiguity & $\begin{array}{c}-0.0738 * * * \\
(0.00666)\end{array}$ & $\begin{array}{c}-0.0609 * * * \\
(0.00668)\end{array}$ & $\begin{array}{l}-0.119 * * * \\
(0.00682)\end{array}$ & $\begin{array}{c}-0.0574 * * * \\
(0.00668)\end{array}$ & $\begin{array}{c}-0.0679 * * * \\
(0.00666)\end{array}$ \\
\hline Common Official Language & $\begin{array}{l}0.119 * * * \\
(0.00799)\end{array}$ & $\begin{array}{l}0.126^{* * *} \\
(0.00804)\end{array}$ & $\begin{array}{l}0.130 * * * \\
(0.00805)\end{array}$ & $\begin{array}{l}0.131 * * * \\
(0.00797)\end{array}$ & $\begin{array}{c}0.121^{* * *} \\
(0.00799)\end{array}$ \\
\hline Common Ethnical Language & $\begin{array}{c}-0.0726^{* * *} \\
(0.00778)\end{array}$ & $\begin{array}{c}-0.0772 * * * \\
(0.00781)\end{array}$ & $\begin{array}{c}-0.0771^{* * *} \\
(0.00780)\end{array}$ & $\begin{array}{c}-0.0823 * * * \\
(0.00778)\end{array}$ & $\begin{array}{c}-0.0744 * * * \\
(0.00777)\end{array}$ \\
\hline Common Colonizer & $\begin{array}{c}0.00137 \\
(0.00954)\end{array}$ & $\begin{array}{c}0.0125 \\
(0.00953)\end{array}$ & $\begin{array}{l}0.0204 * * \\
(0.00955)\end{array}$ & $\begin{array}{c}0.0155 \\
(0.00952)\end{array}$ & $\begin{array}{c}0.00704 \\
(0.00955)\end{array}$ \\
\hline Constant & $\begin{array}{c}3.240 * * * \\
(0.0987)\end{array}$ & $\begin{array}{c}2.960 * * * \\
(0.0994)\end{array}$ & $\begin{array}{c}2.916^{* * *} \\
(0.0987)\end{array}$ & $\begin{array}{c}2.923^{* * *} * \\
(0.0998)\end{array}$ & $\begin{array}{c}3.076^{* * *} \\
(0.0993)\end{array}$ \\
\hline Exporter FE & Yes & Yes & Yes & Yes & Yes \\
\hline Product FE & Yes & Yes & Yes & Yes & Yes \\
\hline Observations & $1,922,527$ & $1,922,527$ & $1,922,527$ & $1,922,527$ & $1,922,527$ \\
\hline$R$-squared & 0.589 & 0.589 & 0.592 & 0.589 & 0.588 \\
\hline
\end{tabular}

